\title{
El legista Cernuda en sus escritos
}

\author{
Julián Gómez de Maya \\ Área de Historia del Derecho \\ Universidad de Murcia
}

Recibido: 24.02.2011

Aceptado: 11.05.2011

\begin{abstract}
Resumen: El presente trabajo analiza, como paradigmático, el drama vocacional del poeta Luis Cernuda, estudiante de Derecho y, a la postre, licenciado perplejo ante el encauzamiento de su vida por alguna de las vías profesionales que le abría su titulación, ajenas todas ellas a sus más íntimas inclinaciones... Además, con una sucinta mirada sobre el desenvolvimiento universitario de aquellos otros miembros de la Generación del 27 que cursaron Derecho, se amplia el campo de visión hasta completar acaso una interesante panorámica del fenómeno.
\end{abstract}

Palabras-clave: Vocación jurídica, conflicto vocacional, estudios universitarios de Derecho, Luis Cernuda, Generación del 27.

Abstract: The present work analyses, as a paradigm, the vocational conflict of the poet Luis Cernuda. He was a student of Law who, ironically on graduating, was confounded by the way his life was directed down one of the very paths that his studies had opened up for him; all these paths being alien to his most heartfelt inclinations... Furthermore, we broaden the scope of this work with a succinct look at the Univeristy progress of those others of the Generation of 27 who studied Law; and thus give, perhaps, an interesting insight into this phenomenon.

Key words: Juridical vocation, vocational conflict, University studies of Law, Luis Cernuda, Generation of 27.

Sumario: I. Luis Cernuda bajo el árbol de la ciencia. II. La lucha por la vida. III. Los otros juristas de la Generación del 27: III.1. Pedro Salinas. III.2. Dámaso Alonso. III.3. Vicente Aleixandre. III.4. Federico García Lorca. III.5. Manuel Altolaguirre. IV. Recapitulación.

En su edición vigente, el Diccionario de la Real Academia Española da, de primero, a la voz legista el significado de "persona versada en leyes o profesor de leyes o de jurisprudencia", pero no es éste el sentido en que cabe aplicar el término al poeta Luis Cernuda (1902-1963), sino en el de la segunda acepción recogida, más modesta: "persona que estudia jurisprudencia o leyes" -obviemos ahora su clásica oposición a canonista-, por cuanto que 
ciertamente no engendra la pericia en leyes el timbre que le ha franqueado la posteridad ni, por ende, el que justifica la atención a sus estudios jurídicos, tan corrientes, tan inexpresivos por sí solos...

Ya poeta en eclosión, se licenció en Derecho el año 1925, mas nunca llegaría a probarse en el ejercicio de tales saberes oficialmente acreditados: por el contrario, una vez cubierto ese período de aprendizaje definido por aquella secundaria acepción lexicográfica, veremos inhibirse al egresado ante el esperable acceso al nivel de la principal en seguimiento de un condigno cursus honorum, el pertinente a cualquiera de las parcelas laborales servidas por juristas. La clave de una distorsión vocacional ha de estar bien en la eventual resistencia que pueda oponer el medio socio-económico, bien en el fuero interno del propio protagonista; mas poca fuerza podrá hacer o añadir aquélla cuando ya la disonancia se ha fraguado y se ha recrecido en éste: lloverá sobre mojado. Por ende, el preferente acudimiento al testimonio introspectivo se justifica aquí en virtud del objeto enfocado, puesto que, en general, constituye la vocación un aspecto de la personalidad para cuyo examen los datos aportados por los biógrafos valdrán de poco más que de ilustración probatoria: una discordancia entre el expediente académico y el currículo profesional como la observable en Cernuda sólo puede aquilatarse a través del sondeo de la vocación subjetivamente sentida; el venero prístino de información no debe ser otro que el examen reflexivo del educando, siempre que tengamos la fortuna -como es el caso- de que nos haya legado su consignación escrita. No es el poeta del 27, desde luego, memoriógrafo al uso, pero su desvío de las formas más canónicas del género viene compensado por el hecho de que su obra toda "[...] puede verse como una biografía espiritual, sucesión de momentos vividos y reflexión sobre esas experiencias vitales", de acuerdo con el plácito felizmente acuñado por Octavio $\mathrm{Paz}^{2}$; comprobémoslo, pues.

\section{Luis Cernuda bajo el árbol de la ciencia}

Cernuda, sevillano, accede al alma mater studiorum de su ciudad natal ${ }^{3}$ en $1919^{4}$, bajo el Plan de 1900 y recién nacida la Reforma Silió ${ }^{5}$. Nada nos

\footnotetext{
${ }^{1}$ Diccionario de la lengua española, $22^{\mathrm{a}}$ ed. (2001), t. II.

2 Octavio PAz, "La palabra edificante", en Los signos en rotación y otros ensayos, selec. Carlos Fuentes, Alianza, Madrid, 1971, pág. 130.

${ }^{3}$ Vide, v. gr., Francisco Aguilar PIÑAL, Historia de la Universidad de Sevilla, Universidad de Sevilla, Sevilla, 1991, págs. 155-161.

${ }^{4}$ Hace referencia Francisco LóPEZ Estrada, "Estudios y cartas de Cernuda (1926-1929)", en Ínsula, n. ${ }^{\circ} 207$ (II-1964), pág. 3, a su "Título de Bachiller, expedido por el rector de la Universidad el 14 de agosto de 1919 [...]".

${ }^{5}$ Vide Manuel Martínez NeIRA, El estudio del Derecho: libros de texto y planes de estudio en la Universidad contemporánea, Universidad Carlos III de Madrid/Dykinson, Madrid, 2001, págs. 143-145, 155-156 y 284-291.
} 
cuenta en sus páginas autobiográficas acerca de la decisión de matricularse en la Facultad de Derecho, aunque sí deja bien claro que no era ésa, ni siquiera al comienzo, la vocación a la que se sentía llamado: viendo cercano ya "el fin de tu estancia en la universidad"6 -recapacita-,

mi grado universitario no podía servirme de mucho, porque era de licenciado en derecho y éste nunca me atrajo ${ }^{7}$.

Con el doctor Marañón en un luminoso ensayo, "hay que tener en cuenta que los seres humanos vivimos sujetos a la gran tragedia [...] de que hemos de elegir nuestra profesión o destino social en una edad en la que la vocación, que es, en su fondo biológico, aptitud, no ha madurado todavía. Salvo casos rarísimos, geniales, de vocación pura, precoz e invencible, la mayoría de los hombres en plena nebulosidad de la adolescencia, al llegar una edad esquemática igual para todos, siendo todos diferentes hemos de decidir nuestro futuro social sin otra razón de peso que la de que somos bachilleres en junio y antes del próximo octubre hemos de estar matriculados en esta o en la otra Escuela Superior, Taller o Facultad. El hombre, que no se conoce nunca a sí mismo, es justamente en esos años amorfos cuando se conoce menos. Y decide nuestro porvenir el consejo de cualquiera o la simple imitación a un amigo, o la tradición familiar, o el mandato del padre, o cualquier otro motivo no menos impregnado de azar y no menos ajeno a la genuina vocación, aun dormida" . No lo sabemos de fijo, mas todo apunta a que la última motivación explicitada por el erudito patólogo, el mandato del padre, sea la correspondiente al presente supuesto vital, habida cuenta del despego cernudiano hacia el mundo del Derecho y de la psicología autoritaria del progenitor, deformación profesional acaso del militar que era ${ }^{9}$. En el diáfanamente autobiográ-

${ }^{6}$ Luis CernudA, “Ocnos”, en Obra completa I. Poesía, ed. Derek Harris et Luis Maristany, Siruela, Madrid, 2002, pág. 581.

${ }^{7}$ Luis Cernuda, "Historial de un libro", en Obra completa II. Prosa I cit., pág. 633.

${ }^{8}$ Gregorio MARAÑón, "Vocación y ética" y otros ensayos, Espasa-Calpe Argentina, Buenos Aires, 1946, pág. 27. Y sucede desde siempre que "se reservaba la palabra para la vocación religiosa, la que se pone directamente al servicio de la trascendencia; lo demás, simples gustos. Faltó una teología general de la vocación" (José María GARCía Escudero, El escándalo del cristianismo, Desclée de Brouwer, Bilbao, 1976, pág. 27).

${ }^{9}$ Miguel Jaroslaw FLYS, "Introducción biográfica y crítica" a Luis Cernuda, La realidad y el deseo, Castalia, Madrid, 1982, pág. 21, subraya "[...] la actitud autoritaria del padre que mantiene una disciplina rígida en su hogar". Para James VALENDER, "Cronología: 1902-1963", en id. (ed.), Entre la realidad y el deseo: Luis Cernuda (1902-1963), Sociedad Estatal de Conmemoraciones Culturales/Residencia de Estudiantes, Madrid, 2002, pág. 109, “[...] resulta evidente que la familia Cernuda Bidón no era una familia cualquiera. La formación militar del padre se dejó sentir en la casa, donde la disciplina familiar fue muy estricta y la comunicación afectiva entre unos y otros muy escasa. La tentación de retirarse a un mundo imaginario propio era, por lo tanto, aún más aguda que en la mayoría de las familias burguesas o pequeño-burguesas de la época, donde de todos modos las decisiones del padre te- 
fico poema "La familia" se nos presentan el padre adusto, la madre caprichosa ${ }^{10}$, "recibiendo deleite tras de azuzarte a veces / para tu fuerza tierna doblegar a sus leyes" "11 bajo "[...] la pobre tiranía que levantaron" ${ }^{2}$ :

Aquel amor de ellos te apresaba

Como prenda medida para otros,

Y aquella generosidad, que comprar pretendía

Tu asentimiento a cuanto

No era según el alma tuya ${ }^{13}$.

Los argumentos del padre -si es que se los dio ${ }^{14}$ - debieron de ser semejantes a aquéllos que el de Ramón de Garciasol tuvo para éste: "lo otro, la filosofía o lo que sea, lo estudias por tu cuenta. Quédate con lo seguro"15. Empero, el cursar Derecho no era según el alma del joven Luis... Y, entonces, ¿qué lo era?:

nían que ser obedecidas de inmediato y al pie de la letra". Vide la anecdótica caracterización del patriarca contenida en el homenaje al poeta de su amigo Rafael MARTínEZ NADAL, Españoles en la Gran Bretaña: Luis Cernuda (el hombre y sus temas), Hiperión, Madrid, 1983, pág. 26, con el sobrecogedor corolario del unigénito: "le molestaba mi presencia".

${ }^{10}$ Cernuda, Poesía cit., pág. 334 (vs. 9-10).

${ }^{11}$ Cernuda, Poesía cit., pág. 335 (vs. 45-46).

${ }^{12}$ Cernuda, Poesía cit., pág. 336 (v. 66).

${ }^{13}$ Cernuda, Poesía cit., pág. 336 (vs. 57-61).

${ }^{14}$ En la visión de Eloy SÁNCHEZ Rosillo, La fuerza del destino: vida y poesía de Luis Cernuda, Universidad de Murcia, Murcia, 1992, pág. 32, se sintetiza en que "[...] seguramente presionado por su familia, se decide sin meditarlo demasiado por la de Derecho, que era en aquel tiempo la preferida de la juventud española procedente de la burguesía. La elección, no hace falta decirlo, no podría haber sido más desacertada. La aridez del estudio de los diversos códigos y las severas disciplinas amontonadas en los gruesos libros de texto, poco tenían que ver con el espíritu libre e imaginativo de Cernuda ni con su temprana propensión a rebelarse contra las normas a las que -según el poeta empezaba a considerar- las clases dominantes de la sociedad, para salvaguardar sus intereses y privilegios, asignan arbitrariamente el nombre de ley. Esta circunstancia dio lugar a que los resultados conseguidos por Luis Cernuda en la Universidad quedaran bastante lejos de la brillantez". En substancia, ante los hechos constatados, no caben otras diferencias que las de la matización; así lo ve, por ejemplo, VALENDER, "Cronología..." cit., pág. 112: "si la decisión de estudiar esta carrera fue tomada por el propio Cernuda, no lo sabemos, pero no es imposible. Dicha elección, desde luego, era algo muy normal en un hijo de familia acomodada de la época; y no hay indicio, por otra parte, de que el joven sevillano hubiera descubierto todavía su vocación como poeta". Sea como fuere, "[...] siguió el camino habitual de un joven de su clase social" (Jordi AMAT, Luis Cernuda: fuerza de soledad, Espasa Calpe, Madrid, 2002, pág. 41).

${ }^{15}$ Ramón de GARCIASOL, "Autopercepción intelectual de un proceso histórico: noticias autobiográficas", en Anthropos, n. ${ }^{\circ} 103$ (1989), pág. 32: "mi padre quiso -sentido prácticoque fuese abogado. [...] La opinión general sostenía que fuera de lo útil, lo demás se quedaba en irrespetable: médico, abogado, ingeniero. Por eso hay tanta burocracia y administrativismo en España, país conservador del parco pedazo de pan. En el caso de mi padre era el dictado de la experiencia, que alicorta en nombre de la seguridad, la voz del escarmiento en cabeza propia". Vide la nota 172 . 
No recuerdo que, antes de sorprenderme a mí mismo descubriéndome una vocación poética, hubiese yo pensado, ni deseado, ser poeta, aunque mi aceptación del hecho siguiera al despertar de la vocación. Ya entrado en la edad madura, volviendo sobre mi niñez y adolescencia, percibí cómo todo en ellas me había preparado para la poesía y encaminado hacia ella. Y, como un poeta lo dijo: "el niño es padre del hombre"16.

Sí, Luis Cernuda, mirando dentro de sí, “[...] ya comenzaba a entrever que el trabajo poético era razón principal, si no única, de mi existencia"17, el sagrado o paraíso interior cuando fugitivo y "[...] asfixiado en suma por el triple y hórrido círculo familiar, amistoso y nacional, me revolvía a uno y otro lado, buscando un poco de frescor, un poco de naturaleza y de libertad"18. Ello no obstante, hubo de frecuentar, velis nolis, aulas y asignaturas bien extrañas a sus intereses. Resulta muy significativo, a este respecto, el exiguo peso que las materias estrictamente jurídicas alcanzan incluso en sus recuerdos de la Universidad:

En mi primer año de estudios universitarios había sido yo alumno de Pedro Salinas, como catedrático que él era, en Sevilla, de Historia de la Lengua y Literatura Españolas. Mas por una incapacidad típica mía, la de serme difícil, en el trato con los demás, exteriorizar lo que llevo dentro, es decir, entrar en comunicación con los otros, aunque algunas veces lo desee, durante el curso no fui para Salinas sino un alumno más, y de los menos distinguidos, entre el medio centenar de ellos que debió tener durante el año escolar $1919-1920^{19}$.

Salinas, decano de la Generación de 1927, puesto a evocar al antiguo alumno, le aplica cervántico y muy sugerente apelativo: “¡no me lo he perdo-

${ }^{16}$ Cernuda, "Historial...” cit., pág. 625.

${ }^{17}$ Cernuda, "Historial...” cit., pág. 630. En la evocación de su condiscípulo José de MonTES, "Texto en facsímil", en Julio M. de la Rosa, Luis Cernuda: inéditos, RC Editor, Sevilla, 1990, pág. 51, "con lecturas como estas que expliquen [sic], continuamos los cursos universitarios. Durante ellos nunca vislumbré que Cernuda escribiera poesias. Es mas, guardó celosamente el secreto de su vocación activa, si es que la ejercitara. En contraste con esto muchas veces me enseñaba pequeñas acuarelas o dibujos [...]. Durante mucho tiempo he conservado esas láminas sin valor alguno, y que el curso del tiempo se encargó de destruir. / La primera vez que tuve conocimiento de una poesia escrita por Cernuda me llamó mucho la atención, pero no me sorprendió. Leí el poema y me gustó mucho [...]. / Esto coincidió quizá con el ultimo año de mis estudios universitarios. Cernuda quedó rezagado en la terminación de la carrera, no recuerdo por que causa, si fué con motivo del servicio militar o de cualquiera otra circunstancia".

${ }^{18}$ Luis Cernuda, "Carta a Lafcadio Wluiki”, en Prosa I cit., pág. 802.

${ }^{19}$ Cernuda, "Historial..." cit., págs. 626-627. Registra esa incapacidad comunicativa un antiguo conmilitón, tanto en el cuartel como en las aulas, Joaquín ROMERo MURUBE, Los cielos que perdimos, ed. María Fernanda González Llamas, ABC, Sevilla, pág. 120, a la hora de redactar su gacetilla necrológica: "universitario de la calle del Aire, comenzando ya a reunir tu enorme capacidad de desprecio, de asco, de soledad y lejanía..." 
nado aún! ¡Y ya va para veinticinco años! No le conocí, de primeras. ¡Meses y meses, de octubre a mayo, sentados frente a frente, aula número cuatro, Universidad de Sevilla! ; Y nada! [... ] Pero él era alumno oficial de mi clase de Literatura; mi año primero de enseñanza. Los dos novicios, él en su papel, yo en el mío. Y no le conocí, y se estuvo cerca de un año un profesor -iy de Literatura!- delante del poeta más fino, más delicado, más elegante que le nació a Sevilla, después de Bécquer, sin saberlo. / Claro es que él entonces apenas escribía y nunca me enseñó un poema suyo. Pero ¡eso qué tiene que ver! No me lo he perdonado aún. ¿Me lo habrá perdonado él? / [...] Difícil de conocer. [...] Por dentro, cristal. Porque es el más licenciado Vidriera de todos, el que más aparta la gente de sí, por temor de que le rompan algo, el más extraño" ${ }^{20}$. Contra el tropo habrá de rebelarse el aludido a la hora del ajuste de cuentas con quien antaño fuera su mentor literario ${ }^{21}$; lo hace en el poema "Malentendu":

Él escribió de ti eso de "Licenciado Vidriera"

Y aun es de agradecer que superior inepcia no escribiese,

Siéndole tan ajenas las razones

Que te movían 22 .

Otros profesores subsisten en su memoria, no muchos $-\mathrm{y}$ aun éstos con denotación negativa-, porque Cernuda es individualista, autodidacto, ensimismado..., y porque aquello le importaba más bien poco, con menor aliciente cuanto más apartado del mester de poetría al que, como oriente vocacional, estaba abocada su existencia.

En cuanto a lecturas filosóficas, la sola palabra filosofía despertaba en mi mocedad una curiosidad intelectual que no reservaba sólo para la poesía. Desgraciadamente, mi curso universitario de historia de la filosofía fue un fracaso. ¿Por culpa mía? ¿Por culpa del profesor? Era éste un anciano que había heredado de su padre, krausista, idéntica profesión filosófica, lo cual

${ }^{20}$ Pedro SAlinas, Ensayos de literatura hispánica, ed. Juan Marichal, Gredos, Madrid, 1967, págs. 372-374. En realidad, parecer ser que no había estado impartiendo clase desde octubre; aduce LÓPEz EsTRADA, "Estudios..." cit., pág. 3, el testimonio de José de Montes González, amigo y condiscípulo del joven Cernuda: "recuerda el señor Montes que en este curso Salinas estuvo en parte ausente, y los alumnos oyeron las explicaciones de literatura de don Cristóbal Bermúdez Plata; Salinas llegó en febrero y trató del siglo XVIII y, sobre todo, y con calor, del 98”. En conclusión, debe atenderse a José María BARRERA LóPEZ, Pedro Salinas en la Universidad Literaria de Sevilla, Universidad de Sevilla, Sevilla, 1991, págs. 23-31.

${ }^{21}$ CERNUDA, "Historial..." cit., pág. 627: "no sabría decir cuánto debo a Salinas, a sus indicaciones, a su estímulo primero; apenas hubiera podido yo, en cuanto poeta, sin su ayuda, haber encontrado mi camino" (merece consignarse que la fecha de este ensayo es 1958; el poema aducido es posterior sólo en tres años, de 1961, pero ya antes, en 1955, había elaborado una implacable crítica de la poética saliniana en ID., "Estudios sobre poesía española contemporánea", en Prosa I cit., págs. 195-200), tan diferente de ID., "Pedro Salinas y su poesía", en Obra completa III. Prosa II cit., págs. 18-21, artículo redactado en 1929.

${ }^{22}$ Cernuda, Poesía ... cit., pág. 524 (vs. 13-16). 
acaso tiñera sus lecciones que, por lo demás, no alimentaron aquella curiosidad mía a que me he referido. Por mi cuenta leí algo de Schopenhauer y de Nietzsche, y poco después, al estudiar economía (cuyo catedrático quedó para mí como ejemplo de la indiferencia y desdén con que cierto tipo de intelectual español, pedante y vanidoso, podía proceder con sus alumnos), llegué a leer, en traducción pésima y podada en extremo, El Capital ${ }^{23}$.

Aunque ese catedrático de Economía Política y Hacienda Pública, Ramón Carande $^{24}$, “[...] el más significado de los historiadores de las instituciones económicas que ha habido en España" ${ }^{25}$, cuenta con producción memoriográfica de amena factura -y fragmentaria linealidad-, no llega a evocar su extensa etapa en la Facultad sevillana ${ }^{26}$ ni, por descontado, a tan retraído y disconforme alumno... Por lo que a éste toca, nos ha dicho algo de las materias seguidas en su paso por las aulas: Literatura, Filosofía, Economía, sí; ¿pero dónde queda el Derecho?: conforme se ha ido viendo, demasiado lejos de las inquietudes del joven Cernuda.

Había en el viejo edificio de la universidad, pasado el patio grande, otro más pequeño, tras de cuyos arcos, entre las adelfas y limoneros, susurraba una fuente. El loco bullicio del patio principal, sólo con subir unos escalones y atravesar una galería, se trocaba allá en silencio y quietud.

Un atardecer de mayo, tranquilo el edificio todo, porque era ya pasada la hora de las clases y los exámenes estaban cerca, te paseabas por las galerías de aquel patio escondido. / [...] Aquella tarde, el surtidor que se alzaba como una garzota blanca para caer luego deshecho en lágrimas sobre la taza de la fuente, su brotar y anegarse sempiterno, trajo a tu memoria, por una vaga asociación de ideas, el fin de tu estancia en la universidad.

Nunca el pasar de las generaciones parece tan melancólico como al representárselo en algo materialmente, tal en esos viejos edificios de universidades o cuarteles, por los que discurre cada año la juventud nueva, dejando en ellos sus voces, los locos impulsos de la sangre ${ }^{27}$.

Parece llegado entonces el instante crítico, la hora de la verdad, en la que el estudiante va a encararse por fin consigo mismo y, redimido de la férula pa-

${ }^{23}$ CERnUda, "Historial..." cit., págs. 628-629.

${ }^{24}$ Cfr. nota 49.

${ }^{25}$ Manuel J. PeláEz, "Carande Thobar [o Thovar], Ramón [Regino Manuel Nicolás Mónico]", apud id. (ed.-coord.), Diccionario crítico de juristas españoles, portugueses y latinoamericanos, Universidad de Málaga, Zaragoza/Barcelona, 2005/2008, v. I, pág. 195; y vide Rocío YÑiguez Ovando, Ramón Carande, un siglo de vida, Fundación Universitaria Española, Madrid, 2002, in totum.

${ }^{26}$ Vide Ramón CARANDE, Personas, libros y lugares, Ámbito, Valladolid, 1982, págs. 5 , 13-14 o 30-37, al menos.

${ }^{27}$ Cernuda, "Ocnos" cit., págs. 581-582. 
terna -el cabeza de familia ha muerto a últimos de $1920^{28}$ y la madre le concede acto seguido la emancipación ${ }^{29}$-, pasará a enfrentarse con el opresivo entorno que lo ha estabulado en la Facultad de Derecho:

Apoyado en una columna del patio, pensaste en tus días futuros, en la necesidad de escoger una profesión, tú, a quien todas repugnaban igualmente, y sólo deseabas escapar de aquella ciudad y de aquel ambiente letal. Cosas contradictorias eran tu necesidad y tu deseo, atándote a ambos sin solución la pobreza. Mas aquel problema mezquino, ¿qué valor tenía cuando te veías arrastrado en el avanzar incesante del tiempo, ascendiendo con una generación de hombres para caer luego, perdiéndote con ellos en la sombra? Privado de gozo, de placer y de libertad, como tantos otros, comprendiste entonces que acaso la sociedad ha cubierto con falsos problemas materiales los verdaderos problemas del hombre, para evitarle que reconozca la melancolía de su destino o la desesperación de su impotencia ${ }^{30}$.

He aquí cómo el problema de la vocación, el destino, se reconduce una vez más en Cernuda hacia ese dolorido sentir suyo de acentos tan originales. Pero a la par que está negando los valores establecidos, no deja de afirmar otra axiología de particular, entrañada vigencia:

[...] Entreveía también que yo servía a algo que, en mi caso, no admitía se le diese devoción secundaria ni compartida: la poesía. Tenía además ho-

${ }^{28}$ FLYS, “Introducción...” cit., pág. 25: “[...] a finales de 1920, muere su padre, lo que parece liberarle un tanto de las exigencias de la sociedad en que vive". "Entre padre e hijo no hubo nunca entendimiento. Por eso, la desaparción de don Bernardo [...] fue para Cernuda una especie de liberación. Su muerte, sin embargo, tuvo para la familia grave repercusión económica” (SÁnchez Rosillo, La fuerza ... cit., pág. 34).

${ }^{29}$ Vide transcrita la "Certificación literal de inscripción de nacimiento", con su nota emancipatoria marginal, en José María CAPOTE NEBOT, El período sevillano de Luis Cernuda, Gredos, Madrid, 1971, págs. 147-149. SÁnchez Rosillo, La fuerza ... cit., pág. 34, motiva el acto: "la emancipación debió hacerse necesaria cuando la familia, para afrontar la nueva situación económica, hubo tal vez de vender alguna propiedad, porque al otorgársele al muchacho 'los beneficios de la mayor edad, para que pueda regir su persona y bienes', se le concedía ya a éste el poder legal de enajenar la parte de la herencia paterna o de alguno de sus abuelos que posiblemente figuraría en las escrituras a su nombre y que no habría podido ser vendida sin el requisito previo mencionado. Paso meramente formal hacia la libertad que, sin embargo, es de suponer que agradaría no poco a Luis, quien cada vez sentía de manera más angustiosa la fría opresión del círculo familiar".

${ }^{30}$ CERnUda, "Ocnos" cit., pág. 582. Glosa el instante SÁnchez Rosillo, La fuerza ... cit., págs. 37-38, con estas líneas: "en la primavera de 1925, cercanos ya los exámenes que pondrían fin a su último año de carrera, Luis comenzó a sentirse desasosegado por los problemas que habrían de presentársele una vez que estuviese en posesión de su título de licenciado en Derecho. La situación económica familiar era precaria y él se vería obligado en seguida a tratar de abrirse camino en una vida profesional que no le atraía en absoluto. Se sentía embargado en aquellos meses por esa peculiar melancolía que siempre nos invade cuando nos damos cuenta de que hemos llegado al final de una etapa de nuestra vida y debemos enfrentarnos con la inseguridad de una nueva y más complicada que la anterior". 
rror a lo que el mismo Rimbaud ha llamado "la mano", el acomodamiento espiritual a un oficio o profesión, y comprendía, no sin terror, ya que la sociedad exige tal acomodamiento de los que deben ganarse la vida, que nunca tendría esa "mano"31.

Tú me escogiste, Poesía, entre los demás; yo, ¿qué había de hacer sino seguirte? ${ }^{32}$

A pesar de todo, va cubriendo el expediente e incluso, según refiere Agustín Delgado, acaso "unas prosas suyas ven la luz en la revista de derecho de la universidad sevillana (1924-1925)" "33. No figuran en su Prosa completa ni he podido hallarlas fuera de ella: quizá se refiera el filólogo a los textos de temática literaria aparecidos en el órgano de la Federación Escolar Sevillana ${ }^{34}$. Lo que sí cabe aportar es el resumen de su expediente académico. En el curso 1919-1920 sigue, en la Facultad de Filosofía y Letras, el Preparatorio de Derecho: ya conocemos el nombre de su profesor de Lengua y Literatura Españolas, D. Pedro Salinas ${ }^{35}$, que le dio un Aprobado en los exámenes de junio, al igual que D. José de Castro en Lógica Fundamental y D. Miguel Lasso de la Vega en Historia de España. La carrera propiamente dicha la comienza el curso 1920-1921: en Instituciones de Derecho Romano, con el profesor D. José López de Rueda ${ }^{36}$, obtiene un Aprobado en los exámenes de junio, pero sendas notas como Suspenso en Elementos de Derecho Natural, que imparte D. Joaquín Campos Murilla, y en Economía Política, asignatura -de acuerdo con lo ya apuntado- de D. Ramón Carande ${ }^{37}$; entrambas materias las recupera en la convocatoria de septiembre con idéntica calificación de Aprobado. El tercer año, 1921-1922, segundo curso de Derecho, sigue la Historia del Derecho Español expuesta por D. Francisco de Casso y Fernández ${ }^{38}$, quien le da un Aprobado en los exámenes de junio, como D. Enrique Martí Gares en Derecho Político Español Comparado; su primer Notable lo consigue, junio

${ }^{31}$ Cernuda, "Historial..." cit., pág. 633.

${ }^{32}$ Luis CernudA, “[Anotaciones] (1926-1927)”, en Prosa II cit., pág. 831.

${ }^{33}$ Delgado, La poética ... cit., pág. 28.

34 "Se trata de aquellas 'líneas de prosa en una revista estudiantil' (recordaría Cernuda en Historial de un libro) que lo pusieron en contacto con Pedro Salinas" -aclaran Derek HARRIS et Luis Maristany [eds.], "Notas" a Luis Cernuda, Obra completa III. Prosa II cit., pág. 829-. Las líneas en prosa corresponden a CERnUdA, "Matices", ibid., págs. 727-728; y el comentario de su autor se contiene exactamente en ID., "Historial..." cit., pág. 627: "ya casi al final de mi carrera, la ocasión de haber publicado yo algunas líneas en prosa en una revista estudiantil, líneas que Salinas leyó, y la mediación de algunos amigos comunes, nos puso al fin en contacto".

${ }^{35}$ Sin embargo, vide la nota 20.

${ }^{36}$ Vide Manuel J. Peláez, "López de Rueda Moreno, José”, apud id. (ed.-coord.), Diccionario... cit., v. I, págs. 488-489.

${ }^{37}$ Vide la nota 25.

${ }^{38}$ Vide Reyes Martín Sánchez, “Casso Fernández, Francisco de”, en Peláez (ed.), Diccionario ... cit., v. I, pág. 207. 
también, de D. Eloy Montero ${ }^{39}$ en Instituciones de Derecho Canónico. El curso 1922-1923 vuelve a superar en junio todas las asignaturas, una de ellas con Sobresaliente: el Derecho Administrativo del profesor D. Carlos García Oviedo ${ }^{40}$; además, logra tres valoraciones de Notable: en Derecho Civil Español I con D. Demófilo de Buen ${ }^{41}$, en Derecho Penal con D. Federico Castejón ${ }^{42}$ y en Derecho Internacional Público con D. Adolfo Moris; el único Aprobado simple de este año es el que D. Ramón Carande, aquel ejemplo de la indiferencia y desdén - a decir de Cernuda ${ }^{43}$-, le concede en Elementos de Hacienda Pública. El siguiente curso, de 1923-1924, no le marchan tan bien las cosas, sin duda por estar cumpliendo, entre 1923 y 1925, el servicio mili$\operatorname{tar}^{44}$ (en la propia Sevilla, en el Tercer Regimiento de Artillería Ligera, acuartelado en la Fábrica de Tabacos, actual sede rectoral de la Universidad y de sus Facultades de Derecho y de Letras ${ }^{45}$ ), pero además por su entrega en alza a los ejercicios poéticos ${ }^{46}$ : las tres especialidades jurídicas de que está matriculado quedan Sin examen en las pruebas de junio, esto es con el alumno no presentado, y sólo en septiembre puede salvar el Derecho Civil Español II, de nuevo con un Notable dado por De Buen, y el Derecho Internacional Privado, con Aprobado de D. Adolfo Mom), mas suspendiendo en Procedimientos Judiciales, disciplina profesada por D. José Xiráu y Paláu ${ }^{47}$. Afronta, pues, el final de carrera ${ }^{48}$ con estos Procedimientos Judiciales pendientes, repasados en el último año académico, 1924-1925, con D. Adolfo Cuéllar, que le otorga su se-

${ }^{39}$ Vide Manuel J. Peláez, "Montero Gutiérrez, Eloy", apud id. (ed.-coord.), Diccionario... cit., v. II, t. I, págs. 163-165.

${ }^{40}$ Vide Manuel J. Peláez, "García Oviedo, Carlos", apud id. (ed.-coord.), Diccionario... cit., v. I, págs. 354-355.

${ }^{41}$ Vide Manuel J. Peláez, "Buen Lozano, Demófilo de", apud id. (ed.-coord.), Diccionario... cit., v. I, págs. 167-168; o Álvaro EsCAURIAZA, "Buen Lozano, Demófilo de", apud Rafael Domingo (ed.), Juristas universales. IV. Juristas del siglo XX, Marcial Pons, Madrid/Barcelona, 2004, pág. 742.

${ }^{42}$ Vide José Garrido ARRedondo, "Castejón Martínez de Arizala, Federico", apud Peláez (ed.-coord.), Diccionario... cit., v. I, págs. 225-226.

${ }^{43}$ CERnUdA, "Historial..." cit., pág. 629 (cfr. nota 23).

${ }^{44}$ Vide la nota 53.

${ }^{45}$ Por aquel entonces, la Universidad de Cernuda estaba "ubicada en la calle Laraña, antigua calle de la Compañía, viejo caserón solemne. En el centro del patio principal, la estatua de Maese Rodrigo. [...] Se trata del lugar donde hoy se alza la Facultad de Bellas Artes de nueva construcción” (La Rosa, Luis... cit., pág. 112). Vide Aguilar Piñal, Historia ... cit., págs. 177-182.

${ }^{46}$ Vide CeRnuda, "Historial..." cit., pág. 626.

${ }^{47}$ Vide Manuel J. Peláez, "Xirau Palau, Josep Ramon", apud id. (ed.-coord.), Diccionario... cit., v. II, t. II, págs. 143-144. Con él ya había coincidido en Murcia, en el noviciado universitario de ambos, CARANDE, Personas... cit., págs. 107-108: "durante mi estancia recibía la facultad de derecho a José Xirau Palau, catedrático de procedimiento que, luego, vendría también a Sevilla".

${ }^{48}$ Vide la nota 17. 
gundo Sobresaliente, y asimismo el tercero, en Práctica Forense; D. Ricardo Checa explica Derecho Mercantil, que Cernuda salda con un cuarto Notable, completando curso y licenciatura en junio ${ }^{49}$ "sin brillantez, pero discretamente, como cumpliendo una penosa obligación impuesta" ${ }^{50} \ldots$

\section{La lucha por la vida}

Una vez egresado de la Universidad, en una situación financiera nada amable, sabrá, a pesar de todo, llevar a la práctica aquellos puros ideales suyos, no sin titubeos y probaturas. De entrada, cree hallar la componenda entre las necesidades materiales y sus inclinaciones temperamentales en el seguro de la función pública, oposición mediante, sucesivamente las de diplomático y las de secretario de ayuntamiento ${ }^{51}$; y es el epistolario la sección de sus escritos que elucida esta encrucijada.

A la espera de ser licenciado también del ejército, prepara, desde que se ve con el título de jurista en la mano, un viaje a Madrid del cual confía en que salga el pretendido encauzamiento hacia la diplomacia. En agosto de 1925 escribe a su compañero de carrera José de Montes ${ }^{52}$ :

Estoy en el cuartel, con un puesto en la oficina; estoy todo lo mejor que se puede estar en un cuartel. Dime cómo sigue lo de tu marcha a Madrid; en cuanto a la mía, si no hay contratiempo, parece asunto decidido ${ }^{53}$.

\footnotetext{
${ }^{49}$ La información académica la tomo de LóPEz EsTRADA, "Estudios..." cit., pág. 3, quien la recaba directamente del archivo universitario.

${ }^{50}$ La Rosa, Luis... cit., pág. 21.

${ }^{51}$ Delgado, La poética ... cit., pág. 28 , lo tiene expresado con desazonadora disyuntiva: "Licenciado en Derecho, no sabe qué camino seguir: a la par le solicitan la creación poética y la necesidad de una regularidad económica. Viendo que le es imposible acceder a la carrera diplomática, que según parece sería su gusto, opta por inclinarse a preparar oposiciones de secretario de ayuntamiento".

${ }^{52}$ Montes, "Texto..." cit., págs. 49-50: “conocí a Cernuda en el curso 1919-20. Fué el año que estudiabamos el preparatorio de Derecho. Ese curso le conocí simplemente a través de las relaciones de compañero. Mi amistad con el nació en el curso siguiente, en el del año 1920-21, y duró hasta que se marchó a Madrid, y aun después en correspondencia desde la Capital, desde Touluces [sic], en donde estuvo de Lector de Español, y en los viajes que yo hice a Madrid hasta la Guerra y los que él hizo a Sevilla al frente de las Misiones Pedagógicas. Despues de la Guerra no volví a tener contacto personal".

${ }^{53}$ Luis CERnUda, Epistolario (1924-1963), ed. James Valender, Residencia de Estudiantes, Madrid, 2003, págs. 13 (c. 15, 15-VIII-1925). Hay rastro epistólico en Cernuda de la bienandanza opositora de este compañero Montes, tan disímil la suerte de ambos a dos: véase ibid., pág. 32 (c. 45, 15-VIII-1926), pág. 39 (c. 56, 2-XII-1926) y pág. 42 (c. 59, 20-XII1926), comenzando con el envío por Cernuda al amigo de un Boletín Oficial "[...] con la convocatoria de oposiciones a Secretario de Ayuntamiento, a las que José de Montes se presentará en diciembre de ese mismo año 1926" (LA RosA, Luis... cit., pág. 85), superándolas (ibid., pág. 82; vide mi nota 70).
} 
Por fin, en los albores de 1926 se desplaza en efecto a la corte, desde donde vuelve a poner unas letras al mismo condiscípulo:

Mi querido Montes: al fin estoy en Madrid aunque sea por poco tiempo, pues no me puedo examinar. Desde luego sería útil para mi preparación -aparte de otra utilidad de orden literario- quedarme para asistir al Instituto Consular como oyente; pero esto no le agradará a mi madre, ni yo por otro lado tengo gran empeño en quedarme: con gran sentimiento mío descubro a Sevilla, sin prejuicio, una vez ahí, de sentir nostalgia de ciudad ${ }^{54}$.

No quede sin resalto esa apenas disimulada otra utilidad de orden literario que en su fuero interno prepondera a todas luces: no hay más que leer completas las dos misivas remitidas a Sevilla desde Madrid para advertir, por el espacio y entusiasmo que alcanza, lo que, a despecho de las perentoriedades crematísticas, interesaba íntimamente a Cernuda: tomar contacto con el medio cultural y artístico capitalino. Por lo demás, claro es que, sin poder desentenderse a su gusto de aquéllas, había procurado canalizarlas hacia algún objetivo o solución acorde con su espíritu ensoñador, todavía dentro de las posibilidades que una preparación jurídica parecía allanar: donde primero creyó encontrar su camino fue en ese sugestivo mundo de legaciones, consulados o embajadas... Ciertamente, en varias ocasiones refiere Cernuda su preferencia e inclinación por la vida nómada, viajera, que fue a fin de cuentas la que acabó viviendo Francia, Escocia, Inglaterra, Estados Unidos, Méjico-, bien es verdad que rebajando el nivel de aburguesamiento con respecto al funcionariado diplomático: siempre sería un profesor eventualmente contratado...

${ }^{54}$ Cernuda, Epistolario... cit., págs. 16-17 (c. 21, 13-I-1926). En la misma circunstancia, el 17 de enero, remite a Higinio Capote Porrúa, otro camarada y concolega, esta noticia: "Mi querido Capote: como el asunto de mis exámenes no se ha resuelto favorablemente, debí salir hoy para Sevilla" (ibid., pág. 18 [c. 22, 17-I-1926]). La mala estrella de Cernuda propició que cuando de algún modo iban a hacerse realidad por fin sus anhelos de trabajar para el cuerpo diplomático, siquiera dentro de la categoría del personal contratado, nuestra Guerra Civil cercenase de nuevo sus ilusiones: en sus cartas queda "[...] la noticia de mi marcha a París. A primeros de agosto iré allá como agregado de prensa en la embajada; por otra parte, El Sol me nombra corresponsal, con lo cual, aun cesando en la embajada, puedo vivir en Francia" (ibid., pág. 197 [c. 252, 9-VII-1936]); junto a Concha de Albornoz (1900-1972), tenía que asistir al nuevo embajador en la capital francesa, padre de esta amiga, don Álvaro de Albornoz (vide María Ángeles LiÑán GARCíA et Manuel J. PELÁEz, “Albornoz Liminiana, Álvaro de”, apud Peláez [ed.-coord.], Diccionario... cit., v. I, págs. 63-64). "No deja de ser curioso y trágico que sea ahora, a las puertas del desastre, cuando cumpla su deseo de estudiante. Siendo tan solo un joven había manifestado a sus pocos amigos el deseo de incorporarse al cuerpo diplomático" (АMAT, Luis... cit., pág. 150), pero, tras pasar el verano en la capital del Sena, "las noticias que llegaban de España abortaron su incipiente carrera diplomática. En septiembre y junto al embajador y su hija, volvían a Madrid reintegrándose en la España leal (como decía la jerga republicana)" (ibid., pág. 152). Con todo, repito que no podía haber tal carrera diplomática, ni aun incipiente: el puesto de agregado de prensa no era oficial, y mucho menos de categoría diplomática. 
Desde niño me atrajeron los viajes, y el espacio comenzó pronto a obsesionarme ${ }^{55}$.

[...] Siempre padecí del sentimiento de hallarme aislado y que la vida estaba más allá de donde yo me encontrara; de ahí el afán constante de partir, de irme a otras tierras, afán nutrido desde la niñez por lecturas de viajes a comarcas remotas ${ }^{56}$.

[...] Y sembrando así para la curiosidad adolescente la semilla, el germen de una dolencia terrible (terrible en el caso, que precisamente era el suyo, de quien, privado de fortuna, debiera afincar en un sitio y pasar allí la vida, ganando en un trabajo ingrato lo suficiente para llegar de un día al otro): la dolencia que consiste en un afán de ver mundo, de mirar cuanto se nos antoja necesario, o simplemente placentero, para formación o satisfacción de nuestro espíritu ${ }^{57}$.

[...] Creo que es necesidad primera del poeta el reunir experiencia y conocimiento, y tanto mejor mientras que más variados sean. [...] En mi caso particular, el cambio repetido de lugar, de país, de circunstancias, con la adaptación necesaria a los mismos, y la diferencia que el cambio me traía, sirvió de estímulo, y de alimento, a la mutación ${ }^{58}$.

No resulta extraño que este ensueño del homo viator, que esta apetencia viajera, por vivir y sentir "como corre la mente de quien muchas tierras anduvo / cuando salta de su corazón reflexivo al recuerdo, 'aquí estuve y allí' y en su mente hay muchísimas cosas" "59 , no parece extraño, digo, que conforme el trasfondo de su querencia hacia el cuerpo diplomático. El estímulo se manifiesta común a muchos profesionales de esta carrera y como tal lo consignan algunos de quienes han abordado la autognosis memoriográfica, como Augusto Conte ${ }^{60}$ (1823-1902), que también estudió en Sevilla, o Francisco Agramonte $^{61}$ (1888-1966), entre otros.

Empero, no pudo cuajarle a Cernuda el efugio salvador y hubo de mesurar sus ambiciones, poniendo entonces miras en el secretariado municipal,

${ }^{55}$ Cernuda, "Historial..." cit., pág. 633.

${ }^{56}$ Cernuda, "Historial..." cit., pág. 659.

${ }^{57}$ Cernuda, "Ocnos" cit., pág. 575.

${ }^{58}$ CERnuda, "Historial..." cit., pág. 639.

${ }^{59}$ Homero, Ilíada, trad. Fernando Gutiérrez, Planeta, Barcelona, 1991, pág. 274.

${ }^{60}$ Augusto CONTE, Recuerdos de un diplomático, Imprenta de Góngora y Álvarez, Madrid, 1901/1903, t. I, pág. 200: "[...] como ya se lo he confesado al lector, no le tenía la menor afición al ejercicio de la abogacía, y por otra parte me moría por ver mundo y visitar los países extranjeros".

${ }^{61}$ Francisco Agramonte, El frac a veces aprieta, Ediciones del Viento, La Coruña, 2008, pág. 15, se pinta a sí propio "[...] nada propenso a tomar excesivamente en serio las vanidades de la Carrera, que en el fondo apenas representaba para él otra cosa que una manera honorable y cómoda de emigrar sin estridencias por algún tiempo". Proyectos análogamente expresados albergó Juan Goytisolo, Coto vedado, Seix Barral, Barcelona, 1985, pág. 142. 
una oposición respecto a la cual no sabemos si llegó a engañarse, pero que a nuestros ojos de cómodos espectadores de una existencia no se presenta ni mucho menos como el destino o escenario, no ya ideal, mas siquiera llevadero para el poeta, para este poeta precisamente. Ya que no acertados, tampoco pecaron de impetuosos sus cálculos, según se deja entender por la morosa deliberación, tras de mucho dar vueltas al incierto porvenir. Cercano el final de ese año 1926, en carta a su colega de estudios Higinio Capote (1904-1954), le informa de los nuevos proyectos:

Mi querido amigo: he pedido a Reus el programa de oposiciones a secretarios de Ayuntamiento, ya que no puedo hacer la carrera diplomática que tanto me gusta, ni la consular, que necesita estudiarse en Madrid para tener probabilidad de éxito. Cuando reciba dicho programa, pediré apuntes para preparar definitivamente esa oposición.

[...]

Siento verdaderamente lo que me dices de ti, ni siquiera puede servir que te diga: yo estoy igual, ya que esto sólo consolará a los imbéciles. Lo esencial para nosotros es convertirnos en funcionarios del Estado. Lo cual, a mí por lo menos, me hace bastante gracia ${ }^{62}$.

La dificultad con que tropezaba el bisoño licenciado para afrontar la pretensión consular era -él nos hace el apunte- de orden económico, por la precisión de sostenerse en la capital de España durante el aprendizaje: al cabo, aquello mismo que lo acuciaba por tan peregrinos rumbos. Sólo una vez enterrado el cabeza de familia, se había hecho cargo su viuda de la precariedad económica en que con sus tres hijos quedaba, y pondría sus expectativas de mejora en Luis, como único varón ya de la casa: era razonable adoptar las medidas precisas para el reajuste de la administración doméstica a la espera de que aquél pudiese hacer productiva cuanto antes la carrera en curso ${ }^{63}$. Ahora, con el mercado laboral abierto para él, el muchacho desdeñaba la socorrida abo-

${ }^{62}$ Cernuda, Epistolario ... cit., págs. 39-40 (c. 56, 2-XII-1926). Tales programa y temario del madrileño Instituto Editorial Reus forman parte de la biblioteca del poeta inventariada por su hermana (vide la nota 95). En la autobiografía del catedrático de Derecho político Adolfo Posada, Fragmentos de mis memorias, Universidad de Oviedo, Oviedo, 1983, págs. 271-273, puede leerse un subepígrafe acerca de esta casa editora. En valoración de SÁNCHEZ Rosillo, La fuerza... cit., pág. 40, "hay que agradecer que las circunstancias impidieran a Cernuda embarcarse seriamente en tales oposiciones, porque, conociendo el carácter del poeta, poco o nada propenso a las diplomáticas maneras, no es difícil suponer que la empresa estaba de antemano condenada al fracaso".

${ }^{63}$ En la exposición de VALENDER, "Cronología...” cit., págs. 114-115: "al morir el general Cernuda, parece que la viuda descubrió, para gran desconcierto suyo, que la economía familiar estaba al borde de la quiebra [...]. La madre evidentemente quería que su hijo, el único varón de la familia, practicara cuanto antes como abogado, y así contribuyera a la manutención familiar, cosa que no parecer haber interesado especialmente al joven poeta en ciernes". 
gacía, en tanto que su plan preferente, las más encumbradas miras diplomáticas, el camino hacia la embajada, esto ya lo tenía por cerrado desde la primera aproximación al terreno. Las palabras del embajador Agramonte, que ingresa en 1910, no pueden ser más expresivas: "[...] ahora, para entrar en la elegantísima carrera, sólo cuentan las recomendaciones. El tribunal no se fija mucho en la inteligencia o la prestancia del candidato, sino en sus blasones, su dinero o los valedores que aporta" ${ }^{64}$. Tal fue, por supuesto, la vía que a él le valió el acceso al prestigioso cuerpo, $\mathrm{y}$ de parecidas experiencias dan fe, a mayor abundamiento, otros diplomáticos precedentes: así, el ático Juan Valera ${ }^{65}$, el supra-

\footnotetext{
${ }^{64}$ No me resisto a copiar el muy plástico pasaje de AGRAMONTE, El frac... cit., págs. 1214, que habla en tercera persona de sí propio: "[...] gracias a la amistad con sus compañeros de la Universidad José y Eduardo Ortega, pasa a servir de secretario privado ad honorem de su padre, don José Ortega Munilla, maestro de periodistas [...]. Una noche menos movida que otras, el jefe le habló afectuosamente para hacerle una proposición ventajosa. Se trataba del acta de Padrón, en Galicia, que en todas las legislaturas era de don José sin disputa. [...] El joven secretario sabía perfectamente que una simple carta con su nombre bastaría para que los electores le eligieran sin molestia ni gasto de ninguna especie. El acta era un pasaporte seguro para subir en su día a la Dirección General, la Subsecretaría, la cartera, tal vez, al fin..., pero ya era tarde. El interesado estaba curado de espanto y sabía cómo se cocinaba todo aquello. [...] 'No, querido don José -le dijo sin pensarlo mucho-; es usted buenísimo conmigo y le agradezco en el alma el deseo de favorecerme en lo que a la mayoría de los jóvenes de mi generación haría felices; pero no sirvo, lo haría muy mal; me horripila entrar en ese mundo de encrucijada y zancadilla. Si quiere usted hacer algo por su fiel secretario de varios años, es muy fácil: recomiéndeme para el ingreso en la carrera diplomática. Si lo consigo, podré irme lejos de este ambiente, que ya me ahoga, y seré probablemente feliz. Ya sabe usted que ahora, para entrar en la elegantísima carrera, sólo cuentas las recomendaciones. El tribunal no se fija mucho en la inteligencia o la prestancia del candidato, sino en sus blasones, su dinero o los valedores que aporta. Sabe usted que hay que entrar como agregado sin sueldo y permanecer un mínimo de tres años en el extranjero haciendo buen papel y viviendo de su propia sustancia'. Don José accedió, se movió lo necesario y, no sin chalaneo y navajeo interno considerable, su recomendado salió con el número ocho de la promoción de diciembre de 1910".

${ }^{65}$ Juan VALERA, "Noticia autobiográfica de don Juan Valera", en Boletín de la Real Academia Española, t. I, c. II (IV-1914), pág. 133: “con mi título de abogado me vine a Madrid a buscar fortuna, sin saber a punto fijo lo que haría; asistí a las fiestas reales cuando el casamiento de la Reina y traté al duque de Rivas, paisano mío, poeta y amigo de mi padre. El Duque mostró que tendría gusto en llevarme consigo a Nápoles, donde era embajador de España, y don Xavier Istúriz me nombró agregado sin sueldo. Fuí a Nápoles con el Duque, y allí olvidé bastante de lo poco que en la Universidad había aprendido. Pasé dos años y medio, haciendo el joli coeur con las damas, siempre en bailes, fiestas y tertulias [...]. Me vine a Madrid con licencia, y me vine tan atolondrado, que no hice aquí sino disparates y tonterías en un año que estuve. Ni siquiera fui a ver a mi jefe el Ministro de Estado. Iba al café del Príncipe, al Prado, a tertulias de trueno y apenas si leía, ni escribía, ni me ocupaba de nada serio. Mi familia, en tanto, viendo cuán costoso era yo y que para nada servía, ni para abogado, ni para periodista, ni para literato, determinó que no servía sino para diplomático, y que si yo no había de arruinarla, era menester que ya me diesen sueldo. En efecto, trabajaron mucho, buscaron empeños y cuando yo menos lo esperaba me encontré con el nombramiento de agregado con sueldo para Portugal"; era el año 1849.
} 
citado Conte ${ }^{66}$ o el zumbón Manuel del Palacio ${ }^{67}$; pero también posteriores, como Máximo Cajal, ya -1959- bajo otra dictadura ${ }^{68}$, cierto que de diverso signo e intensidad a la que se está viviendo ese 1926, aunque no menos proclive al nepotismo, al clientelismo y otros malos ismos por el estilo.

Reintegrándonos al caso Cernuda, lo encontramos en aquel estado y empeño en que se le dejó, frustrado al igual en las rebajadas aspiraciones consulares y decidido a seguir los pasos de su camarada José de Montes, triunfante en la dicha oposición a la Secretaría municipal ${ }^{69}$; unos días después del último anuncio, reitera Cernuda a Capote:

Persisto en hacer oposición a secretario de ayuntamiento. Hoy he pedido los textos. En cuanto a Montes, ganó su plaza; hay pendiente cierta irregularidad cometida por un opositor, pero esto no afectará en nada su bien ganado nombramiento ${ }^{70}$.

A pesar de la dilatada premeditación, de lo rotundo de los términos, poco se desvanece la impresión de que Cernuda no sabe realmente hacia dónde

${ }^{66}$ ConTE, Recuerdos... cit., t. I, págs. 199-200: “[...] vuelvo á mi propia biografía, refiriendo al benévolo lector que una vez constituido el Ministerio de González Bravo, en Diciembre del año 1843, conseguí yo también al fin lo que tanto deseaba, pues ingresé en la carrera diplomática. Varios fueron mis padrinos; pero lo debí principalmente á mis buenos amigos D. Salvador Bermúdez de Castro y D. Juan Comyn", altos funcionarios del Estado y luego también embajadores ellos mismos. "Estos dos amigos, sabiendo cuáles eran mis deseos, tuvieron la bondad de presentarme y recomendarme á González Bravo, el cual me recibió con la más cortés benevolencia y me propuso, desde luego, el puesto de Agregado en Lisboa, que acepté con el mayor placer del mundo". También con Luis González Bravo como dispensador de diplomáticas sinecuras, por igual vale la oferta gubernamental desoída con encomiable probidad por un José ZorRILla, Recuerdos del tiempo viejo, Debate, Madrid, 2001, págs. 241-242 y 251-252; o la tentativa que rememora PosadA, Fragmentos... cit., pág. 142.

${ }^{67}$ Manuel del Palacio, Mi vida en prosa: crónica íntimas, Victoriano Suárez, Madrid, s. a. [1904], págs. 217-218, metido en 1868, a la vuelta de su deportación gubernamental y portorriqueña, a primer secretario y encargado de negocios en Italia por obra y gracia precisamente de Valera.

${ }^{68}$ Máximo CAJal, Sueños y pesadillas: memorias de un diplomático, Tusquets, Barcelona, 2010, pág. 19: "a pesar de la presumible benevolencia del tribunal, los hijos de tres ex ministros de Franco no reunieron las calificaciones mínimas necesarias para ocupar alguna de las diez plazas en litigio. El titular del ramo no lo dudó un instante y, algo inaudito, en plenas oposiciones la convocatoria se amplió a veinte plazas. Los tres opositores aprobaron, por supuesto, aunque fuera raspando, pues ocuparon los últimos puestos de su hornada. Con ellos ingresaron siete afortunados más. Muchos otros se quedaron fuera y algunos, entre los más veteranos, tuvieron la osadía de recurrir. El recurso, naturalmente, fue desestimado". Otras vitandas concesiones de las credenciales embajatorias obviando cualquier atisbo de proceso selectivo, v. gr., en Salvador de MAdariaga, Memorias (1921-1936): amanecer sin mediodía, Espasa-Calpe, Madrid, 1977, págs. 245-248, en 1931; o Antonio GARRIGUES y DíAz CAÑABATE, Diálogos conmigo mismo, Planeta, Barcelona, 1978, pág. 81, en 1962.

${ }^{69}$ Vide la nota 53.

${ }^{70}$ Cernuda, Epistolario... cit., pág. 42 (c. 59, 20-XII-1926). 
quiere encaminar sus pasos, o -mejor-sí que lo sabe: hacia la poesía, pero se ve constreñido por el medio ambiente a atender otras consideraciones, otras prioridades, de acuerdo con el patrón burgués que le están transmitiendo la familia y la sociedad que de dos maneras lo contiene: se espesa ahí otro conflicto -uno más de los que con Cernuda se cebaron- entre la realidad y el deseo. El penúltimo día del año escribe a Juan Guerrero, secretario que fue de algunas de las más célebres publicaciones culturales de aquella hora, pero a la vez secretario del consistorio murciano ${ }^{71}$; a la sazón, quien García Lorca aclamara como cónsul general de la poesía ${ }^{72}$ estaba editando en la capital del Segura las primicias del poeta sevillano:

Pienso prepararme para hacer oposiciones a secretarios de ayuntamiento -de primera categoría-, ya que las circunstancias me impiden prepararme para cónsul, como yo deseaba. Quizá usted pueda proporcionarme algunos datos sobre la mayor o menor dificultad de los estudios, y de obtener puesto. ¿Son éstos en pueblos, casi exclusivamente?

71 "Desde 1925 a 1930, Juan Guerrero fue secretario del Ayuntamiento de Murcia" (Francisco Alemán Sainz, Habitantes de Murcia. Academia Alfonso X el Sabio, Murcia, 1980, pág. 18), pero además "fue Juan Guerrero secretario de toda clase de entidades y comisiones, que le convirtieron en el prototipo de este cargo a muy variados y distintos niveles" (Francisco Javier DíEz DE REVENGA, Revistas murcianas relacionadas con la Generación del 27, Academia Alfonso X el Sabio, Murcia, 1980, pág. 61), "por eso Juan Guerrero -hombre para quien las apariencias eran puro disfraz- fue secretario de muchas actividades, entre ellas secretario del Ayuntamiento de Murcia, secretario del Ayuntamiento de Alicante, secretario de la revista Índice, singular secretario de Juan Ramón Jiménez - de cuya convivencia queda un libro con el rubro Juan Ramón de viva voz-, y en otras importantes secretarías andan Verso y Prosa, con Jorge Guillén, habitante de Murcia por aquellos años, como lo fue también Pedro Salinas. Sin olvidar la famosa página literaria de La Verdad, con José Ballester" (AlEMÁn SAINZ, Habitantes... cit., págs. 16-17); vide mi nota 104. En las memorias del profesor CARANDE, Personas... cit., pág. 107, que pasó por Murcia antes de arribar a Sevilla, conocemos asimismo una faceta más de este secretario de la nueva poesía española, la de profesor: "otro murciano, Juan Guerrero, se vio favorecido muy tarde con el nombramiento de profesor de economía y hacienda pública, después de haber ingresado yo" en aquella Universidad de reciente creación entonces (vide, p. ej., Diego SÁNCHEZ JARA, Cómo y por qué nació la Universidad murciana, Universidad de Murcia, Murcia, 1967, in totum).

${ }^{72}$ Vide Federico García Lorca, Primer Romancero gitano, ed. Christian de Paepe, Espasa-Calpe, Madrid, 1991, pág. 255; más tarde, en carta al aludido, ID., Epistolario completo, ed. Andrew A. Anderson et Christopher Maurer, Cátedra, Madrid, 1997, pág. 552 (c. de 2a quincena de III-1921), repite: "tú siempre el mejor, cónsul general de la poesía". Dámaso Alonso, "Recuerdo y homenaje a Juan Guerrero", en Obras completas, X: Verso y prosa literaria, ed. Valentín García Yebra, Gredos, Madrid, 1993, pág. 687, "quisiera [...] decir, puntualizar, cuán exacta era esa definición y cuán cargada de profundo sentir, es decir, de sentido poético: intuición de aprietamundos, de poeta, de ser que tiene el don mágico de estrujar y condensar, en zumo de muy pocas palabras, mundos de significado". También en Vicente AlEIXANDRE, "Los encuentros", en Obras completas, Aguilar, Madrid, 1968, pág. 1184, topamos con "[...] Juan Guerrero Ruiz, el fiel amigo de la poesía". 
No tengo prisa ninguna por conocer estos datos; cuando necesite escribirme para otra cosa puede entonces, si quiere, dármelos: así su carta no estará dedicada solamente a estas cosas para mí un tanto desagradables ${ }^{73}$.

¿Se puede expresar más palmariamente la escasa implicación espiritual del opositor en sus propios planes? A fin de cuentas, lo que más le inquieta es poder caer en un pueblo ${ }^{74}$, desterrado de todo núcleo literario, en alguna medida más o menos presente siempre en las capitales de provincia... No obstante, a la fuerza ahorcan y él se ve impelido a ponerse manos a la obra en los albores del que habría de ser simbólico año, 1927:

[...] Hace unos días recibí las contestaciones que pedí; y he empezado a estudiar -no necesitaré decirte que sin gran entusiasmo-. Salinas me propone una cosa que a mí me gusta mucho: estar algún tiempo trabajando en el Centro de Estudios Históricos; ya después, con su recomendación, obtendría un puesto de lector en una universidad extranjera. Pero, aun no siendo necesaria una larga estancia en Madrid, un puesto de lector no es cosa deseable a los ojos de una familia -no excepcional ${ }^{75}$.

En verdad, ni a su amigo Capote, que tan bien le conocía, ni a nosotros era necesario hacer evidente esa falta de entusiasmo... Mas, con todo y con ello, ahí anda el opositor a vueltas con su temario, no tan tenaz como resignado. "Sin duda para tranquilizar a su madre, durante algún tiempo Cernuda estudió [...], pero con pocas ganas de presentarse a los exámenes correspondientes (y menos aún de aprobarlos)"76: tal es la impresión de cuantos se acercan a su biografía. Llega así otro verano y en él, ganado por el desánimo, se excusa ante Guerrero, que aguarda originales suyos para Verso y Prosa:

[...] Para su boletín no puedo enviarle más cosas. Aunque mis estudios me dejan tiempo, no me dejan gusto para escribir ${ }^{77}$.

Corre otro medio año y ha de confesar a su íntimo Capote que

${ }^{73}$ CERnUdA, Epistolario... cit., pág. 45 (c. 62, 30-XII-1926).

${ }^{74}$ Y se pregunta LA RosA, Luis... cit., pág. 22: ¿Cernuda diplomático? ¿Cernuda, secretario de Ayuntamiento en un pueblo más o menos perdido, o en el mejor de los casos, en una capital provinciana, asistiendo y padeciendo el espectáculo de una existencia inevitablemente burguesa? El 'carácter como destino' terminará imponiéndose finalmente".

${ }^{75}$ Cernuda, Epistolario... cit., pág. 46 (c. 65, 24-I-1927). LA Rosa, Luis... cit., pág. 23, se detiene caviloso ante "[...] la situación inestable del propio Cernuda en 1927, todavía en su papel de hijo de familia que busca una salida profesional, un oficio digno para el futuro. ¿Cómo soportaría Cernuda, siempre tan distante, esa situación incómoda en una familia burguesa, presidida además por la figura de una madre viuda y enferma? ¿Cómo aceptaría la responsabilidad de ser el hombre de la casa este titubeante licenciado en Derecho, poeta, pendiente de un vago puesto de lector en una universidad extranjera?"

${ }^{76}$ VALENDER, "Cronología..." cit., pág. 115.

${ }^{77}$ Cernuda, Epistolario... cit., pág. 62 (c. 86, 8-VIII-1927). 
Yo mantengo con menos brío el reto a las secretarías municipales. Por las mañanas prosigo acariciando con mis manos uno de esos celestes volúmenes de Reus. Pero creo que no estudio. ¿Dirán lo mismo los respetables miembros del tribunal?.. Es posible.

Procuraré, pues, evitarles tal satisfacción ${ }^{78}$.

El muchacho, tras poco más de un año en el intento, se está sirviendo del hombro leal para sincerarse consigo mismo: se ve con menos brío, sí, tan poco que, por más que echa sus horas delante de los libros, cree que no estudia $^{79} \ldots$

"En julio de 1928 murió mi madre (mi padre había muerto en 1920) y a comienzos de septiembre dejé Sevilla" ${ }^{80}$ : es ésta una decisión muy importante

${ }^{78}$ Cernuda, Epistolario... cit., pág. 77 (c. 104, 25-II-1928). Bien poco tiene esto que ver, por ejemplo, con la pintura del cautiverio de opositor que contemplamos en Joaquín CALvoSotelo, Cinco historias de opositores y once historias más, Espasa-Calpe, Madrid, 1981, pág. 35: "un opositor torturado, víctima de unos apuntes que olvidé en seguida, pero que, en cierto modo, no olvidaré jamás; de una disciplina, una autodisciplina de presidio mayor y una entrega absoluta e incondicional al objetivo que me había propuesto. [...] Persuadido de que la oposición es una trinchera dura de tomar, yo me preparé para su asalto con un cuidado casi científico. Me equipé, por dentro y por fuera, como un soldado que se dispone a la batalla $[\ldots] "$.

${ }^{79}$ No obstante, su innegable fracaso no debió de descender en todo momento a las cotas que imagina SÁnchez Rosillo, La fuerza ... cit., pág. 40: tras el malogro de la diplomacia, "poco después, y mucho más modestamente, decidió Luis dedicar sus esfuerzos a la preparación de unas oposiciones bastante más prosaicas, y tan ajenas a sus aptitudes como las de diplomático: ¡nada menos que las de Secretario de Ayuntamiento! El nuevo proyecto, que hoy no puede hacernos más que sonreír, amargó, sin embargo, no pocas horas de aquel período de la vida del poeta, el cual llegó incluso a adquirir los seis tomos en los que se albergaba el aburrido temario de dichas oposiciones. Hay que advertir inmediatamente, no obstante, para no agraviar la memoria de Cernuda, que el hecho de haber adquirido los mencionados volúmenes no nos autoriza a pensar que el joven llegase siquiera a hojearlos en alguna ocasión. Aunque se lo propusiera seriamente más de una vez, Luis no podía dedicar su tiempo a semejantes ocupaciones. Los libros de estudio descansaban en los anaqueles de su pequeña biblioteca; el polvoriento reposo de los mismos no sería turbado nunca, dada la poco robusta voluntad del muchacho de llegar a ser funcionario público"; asimismo, АMAT, Luis... cit., pág. 71, elucubra igual: "durante unos meses, que yo sepa, no trabajó ni escribió, y a pesar de que la idea de opositar a secretarías municipales aún le bailaba por la cabeza, lo cierto es que no estudiaba. En su biografía se trata de un período vacío que terminó de forma brusca el 4 de julio". En mi sentir, leyendo el correo de Cernuda a Capote, se le ve imponerse una disciplina, comprometerse a la porfía mnemónica, caer en el empeño, ya manos a la obra, ya opositor, pero no antes...; o sea que no trabaja ni escribe porque se aplica en la medida de sus fuerzas -lo cual es bien diferente del abandono inoperante- a preparar la oposición, llenando ésta un período que de otro modo quedaría vacío...

${ }^{80}$ Cernuda, "Historial..." cit., pág. 632. Significa SÁnchez Rosillo, La fuerza ... cit., pág. 44, que "aunque doña Amparo nunca logró entender a su hijo ni aprobó su aparente indolencia, su falta de interés a la hora de buscarse una ocupación 'digna' y bien remunerada, éste quedó muy afectado durante un tiempo por su muerte". 
en la evolución del hombre y del poeta, si es que de algún modo pudieran separarse ambas facetas. Ya nada le retiene allí, se ha confesado el descalabro opositor y entiende que su búsqueda debe discurrir en otra dirección; tras los meses indispensables para liquidar el haber sucesorio, se despide de Sevilla y, con escala en la poéticamente activa Málaga de Prados, Altolaguierre y Litoral $^{81}$, "[...] se marcha a Madrid. Ya no volverá nunca a su ciudad nativa"82 (en realidad, sí que vuelve, fugazmente en $1934^{83}$, pero ya apenas como un forastero). Lo que importa es que este encadenamiento del óbito materno y la salida de su lugar también marca su abandono de la oposición y de toda pretensión de hacer valer su habilitación jurídica en el mercado laboral ${ }^{84}$. De este modo lo expresa a Guerrero y a algunos otros corresponsales:

[...] Yo seguramente me iré a Madrid. Los asuntos naturales en este caso me detendrán aquí. Pero una vez terminados dejaré Sevilla.

Puedo vivir ahora muy modestamente. Lo que usted me dice de Guillén respecto a entrar en La Libertad facilitaría algo mi situación. Y después ya vería.

Oposición por ahora no quiero. Por tanto, le ruego hable del asunto a Guillén. Yo no lo hago porque estoy física y moralmente destrozado ${ }^{85}$.

No olvide -perdóneme: no le importe verme periodista. Eso será para mí algo transitorio. No soy periodista ni sirvo para ello. Pero quiero ganar algún dinero $^{86}$.

Por lo demás, mi situación material sigue tan inestable como siempre. Y mi horror a la oposición continúa también. ¿Cómo concilias ambas cosas? ${ }^{87}$

[...] Tú debes saber bien que la oposición, el puesto oficial, es lo único que asegura, más o menos, económicamente. Yo también lo sé, pero no tengo ánimos, es decir, me conduzco como si no supiera aquella verdad ${ }^{88}$.

${ }^{81}$ Vide, v. gr., Julio NeIRA, Manuel Altolaguirre, impresor y editor, Residencia de Estudiantes, Madrid, 2008, págs. 57-182 y 536-539.

${ }^{82}$ FLYS, "Introducción..." cit., pág. 27.

${ }^{83}$ A su labor dentro de las Misiones Pedagógicas debe Cernuda, Epistolario... cit., pág. 176 (c. 225, 18-VII-1934), este reencuentro: "llegué aquí desde Sevilla, donde pasé unos días después de seis años de ausencia”.

84 "¿Quién era Luis Cernuda en aquel momento? A grandes rasgos y en lo más epidérmico, un licenciado que no ejercía. [...] Como en tantas otras situaciones de su vida, se encontraba en una situación paradójica: no quería opositar (la salida profesional por la que habían optado algunos de sus compañeros de la facultad), pero necesitaba un trabajo con una remuneración suficiente" (АMAT, Luis... cit., pág. 83).

${ }^{85}$ Cernuda, Epistolario ... cit., págs. 86-87 (c. 117, 7-VII-1928).

${ }^{86}$ Cernuda, Epistolario... cit., pág. 88 (c. 118, 15-VII-1928).

${ }^{87}$ CERnUdA, Epistolario ... cit., pág. 117 (c. 158, 7-V-1929).

${ }^{88}$ CERnUda, Epistolario ... cit., pág. 129 (c. 172, 3-X-1929). 
Estoy aburrido, sin esperanzas o con esperanzas insensatas, es lo mismo, y como único proyecto el de no hacer oposiciones en mi vida ${ }^{89}$.

Tampoco el recurso al periodismo se le hace realidad ${ }^{90}$, pero sí lo que depende de sí mismo: la escapada de Sevilla y de las oposiciones o de las exigencias de beneficiar su carrera de jurista, que una y otra cosa van eslabonadas. Al disiparse el conflicto familiar, el atormentado lírico andaluz expande su resentimiento al que ha sido escenario de su infancia y mocedad, la capital bética, la cual, dejada atrás aquella nostalgia de ciudad de su primera estancia madrileña ${ }^{91}$, siente ahora como un entorno hostil, deprimido y deprimente:

Recuerdo de los años pasados en Sevilla. Tiempo perdido, sensación de vacío, de tristeza -años que no fueron míos ni de nadie- ${ }^{92}$.

Se convierte así en un andaluz desterrado en Castilla ${ }^{93}$ y allá, riberas del Guadalquivir, quedan los dilectos libros, los que han arropado sus estudios y, sobre todo, el despertar de su musa; con motivo añorará el poeta "[...] mi bi-

${ }^{89}$ Cernuda, Epistolario ... cit., pág. 136 (c. 179, 27-I-1930).

${ }^{90}$ Con posterioridad, el poeta sevillano seguiría confiando en abrirse paso por esta vía del periodismo y pondría los ojos en distintas cabeceras: El Norte de Castilla, diario vallisoletano en el que su introductor tenía que haber sido asimismo Guillén (CERNUDA, Epistolario... cit., pág. 122 [c. 163, 17-VII-1929]; pág. 123 [c. 164, 18-VII-1929]; pág. 125 [c. 166, 29-VII-1929]; pág. 126 [c. 167, 2-VIII-1929]), el Heraldo de Madrid (ibid., pág. 159 [c. 204, 8-XII-1931]), El Sol, cuya corresponsalía parisina se le escapó con el estallido de la Guerra Civil (ibid., pág. 197 [c. 252, 9-VII-1936]; y vide la nota 54).

${ }^{91}$ Cfr. nota 54.

${ }^{92}$ Luis Cernuda, “[Anotaciones] (1931-1935)”, en Prosa II cit., pág. 754; ID., Epistolario... cit., pág. 94 (c. 127, 27-IX-1928): “creo que no me pesa abandonar Sevilla, la había agotado ya. Allí además no se está en el mundo -bueno o malo es el mundo y así se acepta- sino en Sevilla tan sólo. No hablemos de tantas cosas idas definitivamente; eso constituía para mí una vida que con gran pena, es verdad, veo cómo separan de esta misma persona que escribe. Separan... ¿Quién? El azar o el destino [...]. Yo me decidiría por el último"; ID., "Historial..." cit., pág. 632: "estaba harto de mi ciudad nativa, y aún hoy, pasados treinta años, no siento deseo de volver a ella"; "una constante de mi vida ha sido actuar por reacción contra el medio donde me hallaba. Eso me ayudó a escapar del peligro de lo provinciano, habiendo pasado la niñez y juventud primera en Sevilla, donde la gente pretendía vivir, no en una capital de provincia más o menos agradable, sino en el ombligo del mundo, con la consiguiente falta de curiosidad hacia el resto de él. Eso me ayudó luego a escapar a las modas y complacencias literarias habituales en el ambiente madrileño, no menos provinciano por ser el de la capital" (ibid., pág. 659). No obstante, en la memoria de Rafael ALBERTI, La arboleda perdida, El País, Madrid, 2005, pág. 267, "poeta más 'andaluz y universal' -como quería Juan Ramón Jiménez- nunca lo hubo en Sevilla".

${ }^{93}$ Luis CernudA, "Divagación sobre la Andalucía romántica”, en Prosa II cit., pág. 85. Y pronto, antes incluso de su exilio, será un desterrado de España: "estoy convencido de que España no es posible para mí. Nada tengo aquí. No he hecho un solo amigo. Gentes feas, miserables" (ID., Epistolario... cit., pág. 131 [c. 174, 4-XII-1929]). 
blioteca, que sin faltar a la verdad puedo llamar circulante" ${ }^{\text {" }}$. De su acervo, decididamente vencido hacia la literatura de creación, sacó relación una de las dos hermanas Cernuda, Amparo. Pocos títulos jurídicos entraban allí: cierta Biblioteca de oposiciones. Programa, el Programa de secretarios de Ayuntamientos (seis tomos), las Leyes civiles de España (dos tomos), algún tomo de la Revista de los Tribunales, el Estatuto Provincial, el Estatuto Municipal, y un volumen de Reglamentos ${ }^{95}$; y estos pocos bien se echa de ver que provienen en su mayoría del postrer intento de reconducción jurídica acometido por el poeta en cierne: las improbables oposiciones. Al parecer, esta biblioteca pasó, por disposición de su propietario, a manos del poeta y ganadero Fernando Villalón, el inspirado creador de los Romances del $800^{96}$.

En Sevilla había publicado Cernuda su poemario de presentación, Perfil del aire, en la emblemática fecha de $1927^{97}$. Madrid allana su inserción en la vida literaria, las relaciones con otros creadores y artistas, pero a la vez opone un escollo al libre desenvolvimiento de su musa: la inestabilidad financiera, con tanta energía que, a ratos, hasta torna a acordarse de aquellas viejas ilusiones alimenticias:

La ofensiva literaria como ves, no va mal. Pero quiero dinero, dinero ${ }^{98}$.

[...] Ya que sólo una oposición o algo igualmente difícil podría solucionarme este jeroglífico insoportable. Dinero y dinero ${ }^{99}$.

En el otoño de 1928, fechas previas a su aventura franco-tolosana con el lectorado que le procurara Salinas, incluso le ronda la idea, a instancias del autor de Seguro azar, de hacerse con otra titulación universitaria más acorde con el temperamento que le ha sido dado:

${ }^{94}$ CERnuda, Epistolario ... cit., pág. 139 (c. 182, 27-VII-1930). En la correspondencia cernudiana con sus paisanos más allegados puede rastrearse el éxodo de esta biblioteca juvenil: primero los guarda Villalón (ibid., pág. 133 [c. 176, 23-XII-1929]), despues los recoge Capote (ibid., págs 133-134 [c. 177, 28-XII-1929]), desea Cernuda llevarlos consigo a Madrid (ibid., pág. 155 [c. 199, 11-X-1931]), pero, al cabo, encarga a Capote que los transfiera a su hermana Amparo, la segundogénita, que es quien saca la relación de todos ellos (vide la nota siguiente, 95); por supuesto, en el trasiego por éstas y otras manos que circunstancialmente tienen acceso a las cajas no podrá evitarse el extravío de ejemplares.

${ }^{95}$ CAPOTE NEBOt, El período... cit., págs. 151-160.

${ }^{96}$ En CernudA, Epistolario... cit., pág. 87 (c. 117, 7-VII-1928), le leemos que, ante la inminente partida hacia Madrid, "[...] tendré que separarme de mis libros y papeles. Un equipaje ligerísimo es lo que puedo permitirme" y que "[...] dejo mis libros a Villalón. Pero mis cartas y papeles se los dejo a mi hermana" (ibid. [c. 118, 15-VII-1928]).

97 "El volumen delgado, de sobria y cuidada impresión, llegó a las manos de su ilusionado progenitor en abril. ¿Quién opositaría siendo poeta? Perfil del aire era su presente y su futuro, sus ilusiones y el sentido de todo lo vivido hasta el momento" (АMAT, Luis... cit., pág. 63). Vide CERnUdA, "Historial..." cit., pág. 629.

${ }^{98}$ Cernuda, Epistolario ... cit., pág. 130 (c. 172, 3-X-1929).

${ }^{99}$ CERnuda, Epistolario... cit., pág. 158 (c. 204, 8-XII-1931). 
Tengo a la vista posibilidades distintas: hacer la carrera de letras, es lo que Salinas me indica. Ya veré ${ }^{100}$.

[...] Pienso estudiar bastante: haré la carrera de Letras, y después no sé... Madariaga me escribió dándome amplias promesas; me indicó que estudiara inglés. Salinas -a quien debo lo de Toulouse-me indica la carrera de Letras ${ }^{101}$.

[...] Mis proyectos son varios: el más sensato es hacer la carrera de Letras -Salinas, a quien estoy en extremo agradecido, me aconseja eso-. Pero unas promesas de Madariaga y unas ofertas que me ha hecho una amiga [...] me seducen bastante. Mas es todo esto último inseguro aún ${ }^{102}$.

Hallamos en su epistolario a un Cernuda activo por sortear las dificultades económicas, llamando con dignidad y no sin pudor a cuantas puertas imagina que puedan franquearle el paso hacia una cierta bonanza presupuestaria: así recurre a las amistades más o menos acomodadas en la sociedad que tan impenetrable se le muestra: a Villalón ${ }^{103}$, a Guerrero Ruiz ${ }^{104}$, a Guillén ${ }^{105}$, a Salinas ${ }^{106}$, al librero que siempre suministró los títulos que desde Sevilla encargaba el lector adolescente... De momento, consigue colocarse en el establecimiento de este León Sánchez Cuesta, bibliopola de pro y concuñado, además, de Salinas ${ }^{107}$; de suerte que, en contacto con las novedades editoria-

${ }^{100}$ Cernuda, Epistolario... cit., pág. 98 (c. 133, 31-X-1928).

${ }^{101}$ Cernuda, Epistolario... cit., pág. 99 (c. 134, 2-XI-1928). Recuérdese que fue la capital del Mediodía francés su salida primera al mundo: "Salinas [...] trataba de que la universidad de Toulouse me aceptara como lecteur d'espagnol durante el curso próximo. Económicamente resultaba bien poca cosa, pero era una salida primera al mundo [...]" (ID., "Historial..." cit., pág. 633); poco tiempo adelante, pretenderá -entonces infructuosamentenuevos lectorados el poeta: en Gotemburgo (ID., Epistolario ... cit., pág. 134 [c. 177, 28-XII1929]), en Bratislava y en Oxford (ibid., págs. 140-141 [c. 184, 14-XI-1930]), éste con la gestión corroborada en Pedro SALINAS et Jorge Guillén, Correspondencia (1923-1951), ed. Andrés Soria Olmedo, Tusquets, Barcelona, 1992, pág. 116 (c. 37, 12-XI-1930).

${ }^{102}$ Cernuda, Epistolario... cit., pág. 99 (c. 134, 2-XI-1928).

${ }^{103}$ Cernuda, Epistolario ... cit., pág. 98 (c. 133, 31-X-1928).

${ }^{104}$ CERnUdA, Epistolario ... cit., pág. 124 (c. 165, 25-VII-1929): “otra posibilidad de ganar dinero se me ofrece -escribo 'otra' de una manera estúpida pues no sé cuál será la anterior, esta posibilidad sería por medio de Juan Guerrero, nombrado ahora secretario de Campsa con un sueldo verdaderamente mítico. Si se confirma, como creo, se cambiará en u personaje madrileño. Todo el mundo adquiere posiciones, y yo mientras devoro o satisfago poco a poco, muy poco a poco, mis deseos".

${ }^{105}$ Vide las notas 85 y 90.

${ }^{106}$ Vide las notas 75 y 101.

${ }^{107}$ Por AMAT, Luis... cit., págs. 56-57, averiguamos que "la casa de León Sánchez Cuesta no era una librería más: para conocer los derroteros qe seguían las letras europeas se tenía que pasear la mirada por sus estantes o sus catálogos. Esta librería recibía encargos de toda España (el propio Cernuda había comprado libros franceses por encargo desde Sevilla), distribuía revistas, vendía libros de importación y poemarios de tirada limitada..." (y no sólo literatura gala es la que menudea por la correspondencia comercial entre el joven sevillano y el librero: consúltese ibid., pág. 7 [c. 5, 7-V-1925], como primera muestra conservada, hasta ibid., pág. 88 [c. 119, 28-VII-1928], más luego los varios pedidos desde Toulouse (v. gr., el primero, ibid., pág. 104 [c. 142, 23-XI-1928]; el último, ibid., pág. 116 [c. 157, 25-IV-1929]). 
les y por fin con unos ingresos estables a su disposición, irá introduciéndose poco a poco en la vida social y literaria de la capital:

Entre tanto había hallado un trabajo que, a cambio de la ocupación entera de mi jornada, me dejaba dinero bastante para pasar de un día al otro, lo cual sería casi siempre mi situación económica, aunque luego, afortunadamente, con bastantes menos horas de trabajo y éste de índole más llevadera ${ }^{108}$.

Sigo con la librería. Tiene la ventaja de hacerme ir de un sitio a otro durante el día, y así no me devoro a mí mismo una y otra vez a lo largo de las horas. Con alguna vaga esperanza en perspectiva la felicidad es mía ${ }^{109}$.

Por una serie de circunstancias agradables me encuentro bien en Madrid; con algún dinero más y menos tiempo de trabajo estaría satisfecho (no, no es eso lo que quiero decir, pero no encuentro otra palabra). Y en realidad puedo decir que lo estoy por ahora ${ }^{110}$.

Sin lograr nunca despreocuparse del apremio pecuniario, cuando cambia de empleo, por consiguiente, lo hace buscando tiempo, cuya disponibilidad condiciona el fluido manar de su poesía.

[...] Y por otra parte he abandonado a León Sánchez Cuesta para caer en brazos de las recién nacidas Misiones Pedagógicas: tres horas de trabajo nada más, y trabajo simpático además ${ }^{111}$.

Ahora bien, en todo caso y a despecho de su capacitación rechaza cualquier salida de jurista, resuelto en última instancia a no claudicar más -ya lo hizo a la hora de abrazar carrera, de pasar por opositor-, a no rendir la vocación íntimamente sentida.

Así, frente a la turbamulta que se precipita a recoger los dones del mundo, ventajas, fortuna, posición, me quedé siempre a un lado, no para esperar [...] a que acabaran, porque sé que nunca acaban o, si acaban, que nada dejan, sino por respeto a la dignidad del hombre y por necesidad de mantenerla $^{112}$.

${ }^{108}$ CERNUDA, "Historial...” cit., pág. 637. En su momento, había contado por carta: "hace unos meses que estoy en casa de León Sánchez. Son nueve horas y poco dinero" (ID., Epistolario... cit., pág. 137 (c. 181, 16-VI-1930).

${ }^{109}$ CERnUdA, Epistolario ... cit., pág. 139 (c. 183, 21-VIII-1930).

${ }^{110}$ Cernuda, Epistolario... cit., pág. 144 (c. 188, 2-I-1931).

${ }^{111}$ Cernuda, Epistolario ... cit., pág. 158 (c. 204, 8-XII-1931). "De finales de 1931 hasta principios de 1936, gracias a las Misiones, tuvo un sueldo fijo a cambio de una dedicación horaria breve; esto repercutió positivamente en su producción literaria" (АMAT, Luis... cit., pág. 124).

${ }^{112}$ Cernuda, "Historial..." cit., págs. 660-661. 
"Poeta fatal, obligado por su 'demonio' interior al cumplimiento de una vocación y a la fidelidad a sí mismo" "113: así ha visto Vicente Gaos al poeta de La realidad y el deseo, quien pronto iba a comenzar su colaboración con universidades extranjeras -siempre en el campo de la literatura-, al cabo su modus vivendi tras el abandono definitivo de España, exiliado en $1938^{114}$. Si, ciertamente, "ya no volverá nunca a su ciudad nativa"115 ni aun siente "[...] deseo de volver a ella ${ }^{116}$, cabe concluir, a la vista de la peripecia vital de Cernuda, que tampoco volvería a ocuparse más de las disciplinas jurídicas ni, por supuesto, a sentir deseo de volver a ellas, irremisiblemente arrumbadas donde habite el olvido...

Sin embargo, una actuación postrimera le descubrimos todavía en la condición de jurista... En los meses estivales de 1929 solicita un favor burocrático a su buen amigo Higinio Capote, que sigue residiendo en Sevilla:

[...] Lo que necesito es mi cédula, pero en calidad de transeúnte en Sevilla, con domicilio en Madrid, Fuencarral, 141. Claro que tal vez aquí pudiera obtenerla, pero temo demasiadas complicaciones en esa cuestión de profesión y como resultado en el precio ${ }^{117}$.

Y unos días después, a propósito de ciertas aclaraciones solicitadas por el oficioso factor, es cuando realiza, cargada de carientismo, su afirmación de jurista, acaso conclusiva de una primera etapa de su vida que él no ha podido dirigir:

Mi querido Higinio: no pensaría en sacar mi cédula si no soñara vagamente la posibilidad de un pasaporte para cualquier parte. Por eso quería señalar el domicilio en Madrid. Mas en fin, la dirección de mi hermana es Escoberos, I, $5^{\circ}$. Dirección que te doy con algún temor pues no sé cómo llevará mi hermana esa intromisión titular en su casa. En definitiva, tú da esa dirección para obtener tan sagrado documento. Profesión pongamos abogado. Edad 25 - ¿Alguna sonrisita irónica? ${ }^{118}$ 244.

${ }^{113}$ Vicente Gaos, Claves de literatura española, Guadarrama, Madrid, 1971, t. II, pág.

114 "Y sin volver los ojos ni presentir el futuro, saliste al mundo extraño desde tu tierra en secreto ya extraña" (CERnUdA, "Ocnos" cit., pág. 592). Vide Guillermo de TORRE, Tríptico del sacrificio, Losada, Buenos Aires, 1960, págs. 127-133.

${ }^{115}$ FLYS, "Introducción..." cit., pág. 27.

${ }^{116}$ CERnUdA, "Historial...” cit., pág. 632.

${ }^{117}$ CERnUdA, Epistolario... cit., pág. 122 (c. 163, 17-VII-1929).

${ }^{118}$ Cernuda, Epistolario ... cit., pág. 124 (c. 165, 25-VII-1929). Ibid., pág. 126 (c. 168, 3-VIII-1929), escribe al solícito Capote "[...] para agradecerte la solución a ese asunto de la cédula". 
Ironía la hay en ese quitarse un par de años ${ }^{119}$, también sin duda en esta profesión para la que nunca se sintió llamado y que al fin había tenido el coraje de quitarse también de encima... Cuando Gerardo Diego, con su proyecto de antología generacional entre manos, solicite de los poetas electos o selectos unas referencias biográficas para situar su producción, un mortificado Cernuda responderá -y así hubo de pasar al florilegio dieguiano ${ }^{120}$ :

No valía la pena de ir olvidando poco a poco la realidad para que ahora fuese a recordarla, y ante qué gentes. La detesto como detesto todo lo que a ella pertenece, mis amigos, mi familia, mi país ${ }^{121}$.

No cabe mayor hastío del pasado. Circunscritos a uno solo de los aspectos de ese repudiado ayer, contemplamos la historia de una elección al redopelo, de espaldas a la vocación y a las aptitudes del escolar. Con toda evidencia, los actores del drama no habían hecho lectura del doctor Huarte de San Juan ni el examen de ingenios por él propugnado: "porque, considerando cuán corto y limitado es el ingenio del hombre para una cosa y no más, [...] $y$, porque no errase en elegir la que a su natural estaba mejor, había de haber diputados en la república, hombres de gran prudencia y saber, que en la tierna edad descubriesen a cada uno su ingenio, haciéndole estudiar por fuerza la ciencia que le convenía, y no dejarlo a su elección" ${ }^{122}$, siempre sobre la base científica de "[...] que a cada diferencia de ingenio le corresponde, en eminencia, sola una ciencia y no más; de tal condición, que, si no aciertas a elegir la que responde a tu habilidad natural, ternás de las otras gran remisión, aunque trabajes días y noches" ${ }^{123}$. Desde el mismo frontispicio Huarte hará

\footnotetext{
${ }^{119}$ Otra vez se le sorprende quitándose edad, p. ej., en CERnUdA, Epistolario... cit., pág. 150 (c. 192, 4-III-1931), cuatro años ya de menos.

${ }^{120}$ Las variaciones con respecto al original epistólico son mínimas, si bien el editor Diego le antepuso, de su cosecha, que "se licenció en Derecho, pero no ha ejercido la carrera de abogado" (vide VV. AA., Poesía española. Antología 1915-1931, selec. Gerardo Diego, Signo, Madrid, 1932, pág. 423). Léase la carta de Diego a Guillén en Pedro SALINAS, Gerardo DiEGO et Jorge Guillén, Correspondencia (1920-1983), ed. José Luis Bernal Salgado, Pre-Textos, Valencia, 1996, págs. 128-129 (c. de 20-XII-1930). En torno a las disputas suscitadas por la pretensión de que los propios autores le proporcionaran noticia de sus respectivas vidas, consúltese Gabrielle Morelli, Historia y recepción de la "Antología poética" de Gerardo Diego, Pre-Textos, Valencia, 1997, passim. Con ceñimiento al caso Cernuda, léase ibid., págs. 200201, o váyase a Carlos Morla Lynch, En España con Federico García Lorca (Páginas de un diario íntimo, 1928-1936), Renacimiento, s. 1., 2008, págs. 210 y 232-235; y, pues el conflicto se prolongó en la segunda edición, a SALINAS, DiEGo et GuILlén, Correspondencia... cit., pág. 167 (c. de 15-III-1934); y a SALINAS et GuILLÉn, Correspondencia ... cit., págs. 159160 (c. 52, 17-III-1934).

${ }^{121}$ Cernuda, Epistolario ... cit., pág. 151 (c. 192, 4-III-1931).

122 Juan HuarTe DE SAn Juan, Examen de ingenios, ed. Guillermo Serés, Cátedra, Madrid, 1989, págs. 149-151; y reincide sobre el arbitrio del examen en pro de la república a lo largo de todo el libro: págs. 222-224, 230, 247, 477, 489...

${ }^{123}$ HuARTE de SAn JuAn, Examen ... cit., págs. 159-160.
} 
del examen la causa y el objeto de su empeño intelectual ${ }^{124}$ : no es suya la originalidad de la idea, pero sí su andamiaje especulativo, el metódico desarrollo y la acabada presentación; las divergencias del navarro respecto a otros autores parangonables no serán quizás de enfoque, mas su cimentación teorética está marcando las distancias en todo momento. De manera expresa, tiene el Examen un capítulo "Donde se prueba que la teórica de las leyes pertenece a la memoria; y el abogar y juzgar, que es su práctica, al entendimiento; y el gobernar una república, a la imaginación" ${ }^{25}$; pero asimismo, si bien con consideración dispersa, una serie de observaciones - una tesis- sobre la entidad de la poesía y del poeta ${ }^{126}$. Tan benéfica higiene académica, dicho examen, estaba ya enunciada -sirva la muestra- en el obispo Rodrigo de Zamora $^{127}$, el maestro de cánones Juan Alfonso de Benavente ${ }^{128}$, el canónigo Alonso Ortiz ${ }^{129}$, el conspicuo Nebrija ${ }^{130}$ o el impar Juan Luis Vives ${ }^{131}$; y, junto

124 "Por no hacer hoy día esta diligencia, han destruido la cristiana religión los que no tenían ingenio para teología, y echan a perder la salud de los hombres los que son inhábiles para medicina, y la jurispericia no tiene la perfección que pudiera por no saber a qué potencia racional pertenece el uso y buena interpretación de las leyes" (HUARTE DE SAN JUAN, Examen... cit., págs. 152-153).

${ }^{125}$ HuARTE de SAn JuAn, Examen... cit., págs. 466-492, correspondiendo al capítulo XIII de la edición corregida y aumentada de 1594, antiguo XI en la princeps de 1575.

${ }^{126}$ HuARTE de SAN JuAn, Examen... cit., págs. 202-203, 306-308, 312-314, 394-396.

${ }^{127}$ Rodrigo [SÁNCHEZ DE ARÉvALO], "Del arte, disciplina y modo de criar e instruir a los hijos en su niñez y juventud", ed.-trad. A. Romero Marín, en Anales de la Asociación Española para el Progreso de las Ciencias, t. III, n. ${ }^{\circ} 3-4$ (1939), págs. 564-584, obra de 1450 que corre vertebrada por una idea central: "Que los jóvenes deben dedicarse a lo que esté de acuerdo con sus naturales disposiciones" (cap. IX, págs. 576-579).

${ }^{128}$ El canonista Juan Alfonso de BENAVENTE, Ars et doctrina studendi et docendi, ed. Bernardo Alonso Rodríguez, Universidad Pontificia, Salamanca, 1972, pág. 46, dedica su opúsculo de 1453 a los jóvenes alumnos haciendo gravitar su desarrollo sobre los presupuestos psicológicos de la elección de especialidad de estudio, "quia quilibet ante omnia considerare debet naturam suma ut uideat an sit aptus ad scientiam addiscendam".

${ }^{129}$ En las postrimerías del siglo XV el canónigo Alonso OrTIZ, Diálogo sobre la educación del Príncipe Don Juan, hijo de los Reyes Católicos, ed.-trad. Giovanni Maria Bertini, José Porrúa Turanzas, Madrid, 1983, págs. 167-169, trata "de cómo sea preciso escudriñar la índole de los jóvenes de manera que cada uno se dedique a aquella actividad hacia la cual su propia naturaleza le lleva".

${ }^{130}$ Persuade Elio Antonio de NeBRIJA, La educación de los hijos, ed.-trad. León Esteban et Laureano Robles, Universidad de Valencia, Valencia, 1981, págs. 143-145, de “[ ...] que cada cual debe ser educado de modo que cultive sus propias cualidades y las fomente mediante el estudio, siendo ayudado según sus propias tendencias. [...] Y como todos no sobresalimos en todas las materias, dedíquese cada cual a aquello para lo que esté más capacitado".

${ }^{131}$ Juan Luis VIVES, "De las disciplinas", en Obras completas, trad. Lorenzo Riber, Aguilar, Madrid, 1947-1948, t. II, pág. 558, no descuida animar a los padres, como más directos interesados, a escrutar en sus vástagos "si tienen las disposiciones convenientes para aquella rama del saber a que piensan dedicarlos" (y recorre el consiliario inferencias de varia condición, ibid., págs. 556-569). 
a Huarte, su cierto racionalizador, el thopos humanista es recogido, aunque ni mucho menos con el mismo despliegue sistemático, por otros componentes de ese emporio intelectual que fue la Baeza del siglo XVI ${ }^{132}$ : la controvertida Oliva Sabuco de Nantes ${ }^{133}$ o Salcedo de Aguirre ${ }^{134}$; y, a través de Feijoo $^{135}$, de Jovellanos ${ }^{136}$, de Balmes ${ }^{137}$, tendrá tan amplio eco posterior que va a llegar, verbigracia, hasta ese otro médico norteño que -sin autoexamense frustró en Baroja ${ }^{138} \ldots$

A despecho de la tan sostenida tradición del ingenio ${ }^{139}$, no resulta insólito el episodio cernudiano ni menos tradicional la elección incoherente o acientífica de carrera u oficio. Sin dejar los estudios jurídicos ni la Universidad hispalense ni el recurso metodológico a fuentes memoriográficas, lo encontramos, por ejemplo, en el periodista José Laguillo (1870-1959) ${ }^{140} \mathrm{o}$ en un in-

${ }^{132}$ Vide, v. gr., Manex Goyeneche, "La Baja Navarra en la época de Huarte de San Juan y la Baeza del Siglo XVI", en Vv. AA., Huarte de San Juan, Escuela Universitaria de Formación de Profesorado de E. G. B. de Pamplona, Pamplona, 1989, págs. 59-63; y Ricardo SÁEZ, "Repercusiones de Huarte de San Juan y la Baeza del siglo XVI", ibid., págs. 81-95.

${ }^{133}$ Vide Oliva SABUCO DE NANTES Y BARRERA, Nueva filosofía de la naturaleza del hombre, ed. Atilano Martínez Tomé, Editora Nacional, Madrid, 1981, págs. 280-282.

${ }^{134}$ Vide Gaspar SALCEDO DE AGUIRRE, "Letra para un estudiante", ed. Esteban Torre Serrano, en Archivo hispalense, t. LXVI, n. ${ }^{\circ} 202$ (1983), págs. 74-80.

${ }^{135}$ Vide Benito Gerónymo FeiJóo y Montenegro, Cartas eruditas y curiosas, Real Compañía de Impresores y Libreros, Madrid, 1773-1777, t. III, c. 28ª pág. 323; o ID., Teatro crítico universal, Real Compañía de Impresores y Libreros, Madrid, 1777-1779, t. VIII, d. $3^{\circ}$, pág. 35.

${ }^{136}$ Vide Gaspar Melchor de Jovellanos, "Memoria sobre la educacion pública, ó sea tratado teórico-práctico de enseñanza, con aplicacion á las escuelas y colegios de niños", en Obras, D. F. de Mellado, Madrid, 1845-1846, t. II, pág. 693.

${ }^{137}$ Vide Jaime BALmes, El criterio, Ramón Sopena, Barcelona, 1981, págs. 12-13.

${ }^{138}$ Vide Pío Baroja, El tablado de Arlequín, F. Sempere y Cía., Valencia, s. a., págs. 204207.

${ }^{139}$ Vide José Quintana FernándeZ, "Los orígenes de la "tradición española del ingenio", en Revista de Historia de la Psicología, v. 22 , n. 3-4 (2001), págs. 505-515. De ahí, v. gr., hasta ID., "D. José de Letamendi y la 'tradición española del ingenio'. Creación de 'institutos de examen de ingenios' y de 'escuelas de genicultura", en Revista de Historia de la Psicología, v. 23, n. ${ }^{\circ}$ 3-4 (2002), págs. 539-552.

140 José Laguillo, Memorias: veintisiete años en la dirección de "El Liberal" de Sevilla (1909-1936), ed. Alfonso Braojos Garrido, Universidad de Sevilla, Sevilla, 1979, pág. 109: "fue el curso 1888-1889, el que me matriculé en la Universidad para seguir preparatorio de Derecho", mas "[...] aprobé los cursos a trompicones, echando el ancla de la veleidad a lo mejor de la carrera, pues cuando las asignaturas de Derecho las tenía casi vencidas, mudé de propósito y me declaré a mí mismo que no servía para las Leyes. Breve coqueteo con la Facultad de Letras, estudiando más por afición que por alcanzar la licenciatura, algo de Arabe y griego, y otro repudio, para permanecer mucho tiempo sin saber qué hacer ni en qué cosa útil ocuparme" (ibid., pág. 114). 
telectualmente superdotado Antonio Gala (1936-) ${ }^{141}$ : con todo lo que separa estos tres casos -Laguillo, Cernuda, Gala-, una sola circunstancia, aunque relevantísima, los hace coincidir, y es la carencia, no ya de la vocación de ser jurista, sino hasta de la voluntad real de hacerse jurista que tan a menudo suple el defecto de aquélla. A Luis Cernuda no es la carrera, sino el examen de sus aptitudes lo que le resulta fallido -quien quiera que tomase la decisión ${ }^{142}$, aquélla no se le hace invencible: aplicado y cumplidor, estudia con el aprovechamiento preciso, mas se ve incapaz de proseguir la farsa encadenando su vida al duro banco de un trabajo para él enojoso.

Pero aún cabe acompañar nuevos ejemplos de desmentida vocación jurídica mucho más cercanos a este Luis Cernuda perplejo ante el encauzamiento de su vida por alguna de las vías profesionales que le abría la titulación exhibible, ajenas todas ellas a sus más intensas propensiones... Con una sucinta mirada sobre el desenvolvimiento universitario de aquellos otros miembros de la Generación del 27 que cursaron Derecho, se ampliará el campo de visión hasta completar acaso una interesante panorámica del fenómeno.

\section{Los otros juristas de la Generación del 27}

Pues se ha hablado de los profesores poetas del 27, ¿por qué no habría de poder hablarse de los juristas poetas? En la nómina de integrantes mayoritariamente aceptados en esta Generación lírica ${ }^{143}$ se cuenta o es posible separar una

${ }^{141}$ Antonio Gala, Ahora hablaré de mí, Planeta, Barcelona, 2000, pág. 233, se nos aparece "en Sevilla, en la facultad de Derecho", "[...] con mis libros de derecho y mi carita pálida de niño que nadie creía que fuese ya universitario" (ibid., pag. 188). De privilegiadas capacidades, no sólo cursa Derecho, también Filosofía y Letras: "yo tenía que estudiar, y estudiaba. En la universidad hispalense yo sacaba los cursos con matrículas de honor constantes, e igual sucedía en Madrid" (ibid., pág. 162); y apostilla que "yo estudié, con sabios maestros, Ciencias Políticas y Económicas en Madrid” (ibid., pág. 163). "Todavía, “[...] después de mi tercera licenciatura, ya con veinte años, le dije a mi padre que me gustaría estudiar medicina. / -No. Te conozco. Luego querrás estudiar arquitectura, o a la vez. / Tenía razón" (ibid., pág. 93). En cuanto a su desempeño como jurista, más en grado de tentativa que de frustración, nos entera de que prepara los "[...] ejercicios de Abogado del Estado", sin éxito, pero feliz por la resultancia (ibid., pág. 151), así como "[...] las horrorosas oposiciones de Administrativo y Fiscal e Hipotecario, al reverso de cuyos apuntes seguía escribiendo poemas" (ibid., pág. 154). En consecuencia, a la postre, "[...] elegí lo que no tenía más remedio que hacer: escribir y nada más” (ibid., pág. 155).

${ }^{142}$ Vide la nota 14.

${ }^{143}$ Verbigracia, el propio Cernuda, que la designa como generación de 1925 (CERNUDA, "Estudios..." cit.,págs. 181-239); SALINAS, "Nueve o diez poetas", en Ensayos ... cit., págs. 360-376; Dámaso Alonso, 'Una generación poética (1920-1936)', en "Poetas españoles contemporáneos", en Obras completas, IV. Estudios y ensayos sobre literatura, 3: Ensayos sobre literatura contemporánea, Gredos, Madrid, 1975, págs. 653-676; Jorge GulLLÉn, Lenguaje y poesía, Alianza, Madrid, 1972, págs. 181-197; GaOs, Claves... cit., págs. 215-251; o Luis Felipe VIVANCO, Introducción a la poesía española contemporánea, Guadarrama, Madrid, 1974, in totum. 
mitad de ellos llegados a la joven poesía española con su licenciatura en Derecho bajo el brazo. Además de Luis Cernuda, formativamente son juristas Dámaso Alonso -doblemente licenciado, en Leyes y en Letras-, Federico García Lorca, Vicente Aleixandre -diplomado también en Comercio- y Manuel Altolaguirre; además, inició estudios de Leyes Pedro Salinas, malogrado como jurista ya en primera instancia, toda vez que no alcanzó siquiera el título académico como tal. Diseccionada la biografía estudiantil, la elección -ya que no vocación- jurídica de Cernuda, no han de quedar sin voz los demás, compulsando al menos - cuando sea factible-cómo vieron su respectivo caso y si, allende la renuncia a hacer valer su titulación, coinciden en algo con el poeta de Los placeres prohibidos.

\section{III.1. Pedro Salinas}

La crucial Antología de la poesía española que en 1932 preparara su oficiante Gerardo Diego divulga de Pedro Salinas (1891-1951) que "estudió en las Facultades de Derecho y de Filosofía y Letras de la Universidad Central, y es doctor en Letras (1917) y catedrático de Lengua y Literatura española (1918)"144. Del decano de la Generación no hay más que decir sino que dejó los bártulos -en pura etimología- y recondujo sus pasos académicos hacia las Letras, aunque no sin vacilaciones, como lo demuestra el hecho de matricularse en la sección de Historia, titulándose en ella, cuando luego sería a las claras la literatura su ocupación vocacionalmente sentida... El vate de los Presagios no ha recreado por escrito este proceso de tanteos y rectificaciones (quizá sí en la parte inédita de su carteo de noviazgo, todavía sin abandonar las aulas jurisprudenciales al ponerse en relaciones ${ }^{145} \ldots$ ); sin embargo, nos entera su hija, Solita Salinas, de que "al terminar el bachillerato en 1908, Salinas ingresó en la Facultad de Derecho por complacer a su madre. Dos años más tarde se matriculó también en la Facultad de Filosofía y Letras, en la sección de historia. Obtuvo la licenciatura en el año de 1913" "146. Y esto sí que lo contó el interesado, precisamente en misiva a su novia y futura esposa, Margarita Bonmatí; las expresiones salinianas, su exultación novel, dejan poco lugar a dudas respecto a que, tras dos cursos siguiéndola, no había persistido ni prosperado más en la licenciatura jurídica, que debió de excluir ${ }^{147}$, como

${ }^{144}$ VV. AA., Poesía ... cit., pág. 167.

145 Solita Salinas de Marichal (ed.), "Notas" a Pedro Salinas, Cartas de amor a Margarita, 1912-1915, Alianza, Madrid, 1986, págs. 15: "en el año 1911, cuando conoce a Margarita, Salinas cursaba Filosofía y Letras y Derecho".

${ }^{146}$ SALinAS DE MARICHAL, "Notas" cit., págs. 85-86.

${ }^{147}$ José María BARrera LóPeZ, El azar impecable (Vida y obra de Pedro Salinas), Guadalmena, Sevilla, 1993, pág. 21: "en los dos cursos académicos, 1909-1910 y 1910-1911, se encuentra matriculado en la Facultad de Derecho, donde obtiene las notas de Notable en Derecho Político, Penal, Administrativo, Civil e Internacional. Si en esta ocasión Doña Soledad sintió una gran felicidad, hubo otras veces donde mostró su disgusto ante las ocupaciones de su hijo lejos de una carrera de leyes, que juzgaba como la licenciatura más práctica". 
ajena a sus inclinaciones, desde que optara por probarse en Letras: ésta en Historia será la primera y única de la que pueda blasonar, pero ha de bastarle, con el indeclinable doctorado ${ }^{148}$, para el acceso a las cátedras de Literatura ${ }^{149}$.

\section{III.2. Dámaso Alonso}

De Dámaso Alonso (1898-1990) destaca la Antología de Gerardo Diego que "obtiene los títulos de licenciado en Derecho y doctor en Letras" ${ }^{150}$. Pero asistamos al relato del errante protagonista:

Desde 1914, al salir del colegio, leí más ampliamente, y también empecé a escribir poesía [...].

Tenía entonces la afición literaria y otra muy distinta: estaba estudiando matemáticas, con intención de lograr mi entrada en la Escuela de Ingenieros de Caminos. Pero tuve que dejarlo, porque, al ir a comenzar la primavera de 1916, se me formó una gravísima úlcera en el ojo derecho. Tuve que dejar de leer. A fines de la primavera empecé a mejorar.

$[\ldots]$

No me atrevía yo a seguir preparándome para la ingeniería. También me equivoqué; me decidí a estudiar lo que poco me iba: Derecho. En parte fue porque no podía leer mucho: mis ojos estaban medianos. Me matriculé libre. Mi madre me leía gran parte de lo que tenía que estudiar. Me examiné en cuatro convocatorias de junio y septiembre de 1917 y 1918 (y de una asignatura en diciembre), y terminé la carrera (Licenciatura de Derecho).

$[\ldots]$

Ese mismo año de 1918 mi pasión por la literatura me llevó a estudiar en la Facultad de Filosofía y Letras, sección de Letras. El año primero era el mismo que el primero de Derecho; lo tenía, por tanto, ya aprobado. Me matriculé oficialmente. Había que ir todos los días, por la mañana temprano, a la Facultad $[\ldots]$.

La licenciatura me duró hasta $1921^{151}$.

${ }^{148}$ BARRERA LóPez, El azar... cit., pág. 22: “el 27 de enero de 1914 se firma su Certificación completa de asignaturas y el 5 de febrero de 1914 verifica en la Universidad de Madrid los ejercicios del grado de Licenciado (sección de Historia)"; "[...] después, hace constar su suficiencia en la Universidad Central de Madrid para el título de Doctor en Filosofía y Letras, sección Historia, con fecha 23 de julio de 1917. Su tesis doctoral versará sobre las ilustraciones de El Quijote a través de los siglos" (ibid., pág. 30).

${ }^{149}$ Pedro SALinAs, Cartas... cit., pág. 109: “[...] acabó de llegar de la Universidad, sabes, de hacer mi examen de Licenciatura de Filosofía y Letras. Ya soy Licenciado en Filosofía y Letras: me han dado de nota sobresaliente. [...] Vida, este examen me ha alegrado más que los demás porque es definitivo: ya tengo mi título de licenciado, ya tengo aptitud para ejercitarlo".

${ }^{150}$ VV. AA., Poesía... cit., pág. 217.

${ }^{151}$ Dámaso Alonso, "Vida y obra", en Antología de nuestro monstruoso mundo / Duda y amor sobre el Ser Supremo, ed. del autor, coord. Margarita Smerdou Altolaguirre, Cátedra, Madrid, 1985, págs. 11-13. Repasa Dámaso SANTos, "Sucedido y sucesivo Dámaso", en VV. AA., Dámaso Alonso, premio "Miguel de Cervantes" 1978, Anthropos/Ministerio de Cultura, 
"También me equivoqué"... Poco más cabe añadir a la introspección del artífice de Hijos de la ira o La lengua poética de Góngora, su recrecida tesis doctoral ${ }^{152}$, ya definitiva y gozosamente en el camino de la Filología.

\section{III.3. Vicente Aleixandre}

Como Cernuda ${ }^{153}$, se negó Vicente Aleixandre (1898-1984) a facilitar al antólogo Diego los datos biográficos que éste necesitaba para exordiar el muestrario de sus poemas contenido en Poesía española. El conspicuo catedrático de instituto trasladó las respuestas epistolares de ambos poetas sevillanos, con algunas leves variantes, a su selecto volumen ${ }^{154}$; he aquí el texto de la carta aleixandriana:

¿Tú crees que a alguien le importa realmente saber que yo vivo en Madrid desde la pubertad, que me hicieron hacerme abogado, que no ejerzo mi carrera (¿mía?) y que no hago más que vivir cuanto puedo y lo que puedo, escribiendo poesía porque es mi necesidad todavía? A nadie le importa [...]. Datos, datos. ¿Pero son estos datos mi vida? [...] Pero yo no puedo ponerme a contar lo que yo no soy; porque todo eso no soy yo, y en eso yo no me reconozco ${ }^{155}$.

Puesto que sólo incidentalmente alude el poeta de Velintonia a sus estudios ${ }^{156}$, habrán de ser sus biógrafos quienes nos participen que "tiene dieciséis años y aquel octubre [1914], superado el preparatorio, ingresará en la Facultad de Derecho. Va a iniciar también los estudios mercantiles. Precisamente la carrera de comercio se va a reorganizar y dignificar por un decreto de principios de 1915.

Barcelona, 1988, pág. 49: "no habrá ingeniero. La gripe -ese fantasma trágico que recorre España de punta a punta- le afecta, con la colaboración de un desacierto médico, a la vista, y se suspenden los preparativos. Será más fácil que su madre le lea hasta que se recobre, y nada más a propósito que las asignaturas de Derecho, que no hay que hacer elucidar [sic] cálculos ni trazar dibujos. / Puesto que podía licenciarse en Leyes en dos patadas, como hay cursos comunes, irá de lleno a Filosofía y Letras". La incursión en la Ingeniería ofrece a su muy allegado AleiXANDRE, "Los encuentros" cit., pág. 1198, la siguiente reflexión: "de su paso por la Matemática le quedaría su vocación de claridad mental y, posiblemente, la precisión en el ajuste de su pensamiento, al ponerse en acción".

${ }^{152}$ Vide Andrew DeBicki, Dámaso Alonso, trad. Manuel Revuelta, Cátedra, Madrid, 1974, pág. 24.

${ }^{153}$ Vide la nota 121.

${ }^{154}$ VV. AA., Poesía ... cit., pág. 401, para Aleixandre. Vide AleiXandre, "Los encuentros" cit., págs. 1194-1197.

${ }^{155}$ Vicente AleiXANDRE, Correspondencia a la Generación del 27 (1928-1984), ed. Irma Emiliozzi, Castalia, Madrid, 2001, págs. 64-65 (c. 11, 14-III-1931).

${ }^{156}$ V. gr., ALEIXANDRE, "Los encuentros" cit., pág. 1167: “yo estaba en Madrid, en la calle de San Bernardo. Cuando se tienen dieciocho años, retrasarse en llegar a clase en la Universidad no importa demasiado" (ibid., pág. 1163); o ibid., pág. 1159: "allí, al lado de aquella escuelita de Comercio donde un muchacho cursaba estudios, había una librería de viejo" (ibid., págs. 1369-1370). 
Es un excelente alumno y el padre tiene reservada para él la realización de grandes proyectos" 157 , así que, aplicadamente, "[...] prosigue sus estudios y termina, en 1919, la Licenciatura en Derecho. Cursa el doctorado en 1920, pero no llega a presentar la tesis. En cambio, obtiene sobresaliente en la Memoria para recibir el título de Intendente Mercantil: 'Régimen de puertos francos', es el tema. [...] Cirilo Aleixandre no cabe en sí de gozo. Su hijo es ya economista. Lo que no sabe, lo que no puede ni sospechar, lo que le dejaría de piedra, es que el flamante economista ha empezado a escribir versos. / Es un secreto que Vicente llevará sin revelar a nadie durante mucho tiempo"158.

De los componentes del 27 que se licenciaron en Derecho es Aleixandre el único que llegó a encarrilar su vida profesional por área más o menos jurídica. El bisoño e inédito poeta ha completado su formación académica "y el mismo año en que termina sus estudios logra un puesto de profesor de Legislación Mercantil en la Escuela Central de Comercio. Aunque no le agrada la materia, la enseñanza no le disgusta, y abandona muy pronto este cargo para ocupar otro en los Ferrocarriles Andaluces. Más tarde colabora en una revista de temas económicos - La semana financiera-, para pasar después siempre realizando un trabajo burocrático- a la Compañía de Caminos de Hierros del Norte de España" 159 .

Pero el poeta paradisíaco está a punto de ser mordido por el dolor físico, un sufrimiento limitador para la vida de mundo, aunque providencial para su ingénita entraña poética, puesto que le trae la redención de aquellas servidumbres profesionales ${ }^{160}$ con una prematura jubilación, con una convalecen-

${ }^{157}$ Leopoldo de LuIs, Vida y obra de Vicente Aleixandre, Espasa-Calpe, Madrid, 1978, pág. 80.

${ }^{158}$ Luis, Vida... cit., pág. 91. Confiesa Vicente AleiXAndre, Mis poemas mejores, Gredos, Madrid, 1976, pág. 15, que “Ámbito, mi primer libro, fue compuesto entre 1924 y 1927. Desde cinco o seis años antes el aprendiz de poeta escribía silenciosamente versos, nunca publicados y hoy desaparecidos".

${ }^{159}$ Antonio Colinas, Conocer Aleixandre y su obra, Dopesa, Barcelona, 1977, págs. 3031. En esta etapa " [...] su vida sufre una serie de forcejeos y tensiones destinados, creo yo, a dejar establecida su personalidad futura y, en consecuencia, su vocación", como "[...] sus tan repetidos intentos de hallar un empleo al margen de la vocación literaria que ya despuntaba" (ibid., pág. 29). "Hay, pues, ya una lucha evidente entre esos cargos que desempeña entre sus 21 y sus 27 años y esa labor creadora, primeriza, pero apasionante, que él lleva a cabo en el mayor de los secretos" (ibid., pág. 31). Vide AleIXANDRE, "Los encuentros" cit., pág. 1380, en torno a "[...] un cursillo sobre algo relacionado con mi flamante título de intendente mercantil. Sí, expliqué como pude, entrando en fuego con mis veintidós años, algo de lo poco que había aprendido sobre técnica y lenguaje comercial castellano".

${ }^{160}$ Del desagrado con que llegó a mirar tales asuntos dice mucho su queja, en suma al insondable dolor filial, ante el papeleo que le aguardaba tras fallecer su progenitor: "estoy triste estos días pensando en mi vuelta a Madrid, aún lejana en cierto modo, pero ya amenazadora. Veo allí todavía habilitado, notario, Instituto de Moneda, etc. etc., cangilones de una noria a la que he de dar vuelta sin afición y sin gusto, prisionero de unas obligaciones de las que estoy deseando evadirme" (Vicente AleIXANDRE, Epistolario, selec. José Luis Cano, Alianza, Madrid, 1986, pág. 30 [c. VII, 12- IX-1940]). 
cia de por vida. Efectivamente, "[...] una grave enfermedad iba a cambiar el curso de su existencia. Quien iba para economista y profesor, quién sabe si para directivo de empresa, se vio convertido impensadamente en un poeta. Fue el año 1925, y la enfermedad -una tuberculosis renal que obligó, siete años más tarde, a la extirpación de un riñón- hubo de apartarle de toda actividad profesional y social. A los veintiséis años, Aleixandre se vio obligado a hacer reposo algunas horas al día, pero esta forzosa inactividad, que limitaba su impulso vital, iba a favorecer su destino de poeta, al permitirle consagrar muchas horas a la poesía y a la lectura, convirtiendo la necesidad y el placer de escribir en una costumbre cotidiana" ${ }^{161}$. He aquí el resumen de su trayectoria curricular: en cualquier caso, datos, datos. ¿Pero son estos datos su vida?

\section{III.4. Federico García Lorca}

A Lorca (1898-1936) el autor del Manual de espumas y Alondra de verdad lo presenta en su reputada Antología con estos timbres: "en la Universidad de Granada y en la de Madrid estudió Derecho y Filosofía y Letras. Es licenciado en Derecho (Granada)"162. En síntesis, su historia universitaria se cifra en la clásica decantación hacia la carrera lucrosa, con la atención en el medro social, lo que significa que García Lorca se vio impelido a realizar unos estudios superiores que quedaban fuera de todo interés personal: así fue a la hora de elegir carrera -en su caso, carreras: Derecho y Letras ${ }^{163}$ - y cuando, ya universitario, evidenciaba con las calificaciones su escasa implicación anímica en la empresa. "Los padres de Federico, empero, estaban empeñados en que tanto él como su hermano hicieran una carrera que les permitiera acceder a una profesión 'útil'. En consecuencia, no le quedaba más remedio al Lorca adolescente que resignarse a ingresar en la Universidad de Granada, y ello por mucho que ansiara dedicarse exclusivamente a la música[ $\left.{ }^{164}\right]$. Así pues, en octubre de 1914, antes de terminar del todo el bachillerato, se matriculó en el curso común que daba acceso a las facultades de Filosofía y Letras y de Derecho. En realidad, éstas eran las únicas opciones posibles que se le ofrecían, ya que las demás facultades -Medicina, Ciencias y Farmacia- eran impensa-

${ }^{161}$ José Luis CANO, Vicente Aleixandre, Ministerio de Cultura, Madrid, 1981, pág. 9.
${ }^{162}$ VV. AA., Poesía... cit., pág. 297.
163 “Con el final del Bachillerato se le plantea el problema de qué carrera empezar. Como buen lector que fue siempre, piensa en la posibilidad de hacer Filosofía, pero sus padres opinan que no es carrera para él; prefieren que haga Derecho, lo que le abriría el camino a una floreciente situación económica. En realidad, ninguna de las dos le apetece y opta por una solución ecléctica: matricularse a la vez en las dos carreras; la de Filosofía no la acabaría nunca" (Arturo MAGARIÑo, Caminos abiertos por Federico García Lorca, Hernando, Madrid, 1982, págs. 35-36).

${ }^{164}$ Compruébese, v. gr., en Francisco García Lorca, Federico y su mundo, ed. Mario Hernández, Alianza, Madrid, 1980, págs. 55-56, 158-159 y 423-430. 
bles en vista de su temperamento y de sus aptitudes" ${ }^{165}$. Los García Lorca, sin duda afectados por la superstición de los títulos que también padeciera el progenitor de Jacinto Benavente ${ }^{166}$, porfiaron sobre Federico y éste hubo de condescender a brindarles siquiera una de las dos licenciaturas en curso. Primero pensó en contentarlos terminando Filosofía y Letras:

Poco a poco el topo doméstico del amor familiar ha ido minando mi corazón en mantillas convenciéndome de que debo, por deber y por educación, terminar mi naufragada carrera de Letras... ¿Qué te parece? Ya había pensado mi madre en que me tenía que marchar a Madrid en octubre y toda la familia estaba conforme, pero con una conformidad resignada, no alegre como yo deseo, a causa de estar mi padre dolorido de verme sin más carrera que mi emoción ante las cosas. Ayer me dijo: "Mira Federico, tú eres libre, vete donde quieras, porque yo estoy convencido de tu extraordinaria vocación por el arte, pero ¿por qué no me das gusto y vas haciendo como quieras tu carrera? ¿Te cuesta algún trabajo? Si en septiembre hicieras alguna asignatura, yo te dejaría marchar a Madrid con más alegría que si me hubieses hecho emperador".

Ya ves, queridísimo, cómo mi padre tiene razón y, como ya está viejo y es gusto suyo el que me adorne con una carrera, ya mi decisión es irrevocable. ¡ Voy a terminar! [...].

Yo lo que quiero es presentarle a mi padre en septiembre unas cuantas papeletas para darle un alegrón y marcharme tranquilo a publicar mis libros ${ }^{167}$.

${ }^{165}$ Ian Gibson, Vida, pasión y muerte de Federico García Lorca, Plaza \& Janés, Barcelona, 1998, pág. 60. De entrada, "[...] se matriculó simultáneamente en las facultades de Derecho y de Filosofía y Letras. Se trataba de un procedimiento bastante corriente en la época, por dejar abiertas más posibilidades profesionales futuras. Y, como el trabajo tampoco era muy exigente, eran muchos los estudiantes que conseguían sin demasiados problemas las dos licenciaturas" (ibid., pág. 64). "Y es curioso que siendo más idónea la segunda para sus aficiones literarias, sea la primera la que finalizó en 1923" (Aurora DíAz-PLAJA, Federico García Lorca, Hisma, Barcelona, 1977, pág. 24).

${ }^{166}$ Jacinto BenAVENTE, Recuerdos y olvidos (Memorias), Aguilar, Madrid, 1959, pág. 119 (por igual, ibid., págs. 420 o 426).

${ }^{167}$ Federico GarCía LorCa, Epistolario... cit., págs.77-78 (c. de 27 [¿agosto 1920?]). Es contextualización de Francisco GARCía LorCA, Federico... cit., págs. 175-176, que "era una época en que los traslados por razón de estudios eran normales, si bien lo frecuente era que los estudiantes concurriesen a las instituciones locales. No era ni remotamente pensable que un sevillano viniese a Granada a estudiar, o viceversa. Tampoco se daba el caso de que una Facultad atrajese por su prestigio a estudiantes de comarcas alejadas. Lo que importaba en aquella sazón no eran los estudios, sino el título, y tan oficial era el de una Universidad como el de otra, así fuera ésta la más pintada. / Por lo tanto, la ida a Madrid no se planteó nunca en casa, ni antes de terminar Federico la carrera, como un viaje de estudios; era, pues, viaje literario, si bien muy vagamente. Estaba muy vivo en provincias el prestigio de Madrid como centro de actividades culturales. Era razón que así fuese. No hay para qué hablar, aparte lo ya reseñado, de la vida intelectual de provincias. Pero había también un cierto papanatismo provinciano: no se podía ser de veras escritor, ni pintor, ni poeta, si no se triunfaba en Madrid". 
Lo primero que hace es tantear qué asignaturas resultan más fáciles de camelo o en cuáles puede contar con recomendaciones ${ }^{168}$. A pesar de ello y aunque a su familia informe de que "voy muy bien de mis estudios" 169 -eso sí, "ahora estudio (no para matarme) de una manera regular, como se debe estudiar; [...] pero en cambio leo desaforadamente y sobre todo escribo"-, lo cierto es que a la larga acaba por pedir cuentas "mi familia, que está disgustada conmigo porque no he aprobado las asignaturas" ${ }^{170}$. Es ante este fracaso de su primer intento de licenciarse a toda costa cuando debió de mudar el objetivo, persuadido acaso de la mayor asequibilidad de los aprobados precisos en Derecho; y no le fue mal el plan, pues al cabo de un año, ya con referencia a las disciplinas jurídicas, puede presumir de que

He aprobado diez asignaturas y terminaré la carrera en enero. Entonces mi señor papá me dejará correr tierras ${ }^{171}$.

Así sucedió, en efecto. Su hermano menor Francisco, que se haría abogado notable y diplomático por oposición, le ayudó en la tarea, junto a otras ayudas más valiosas y expeditivas, como decantadas sin rebozo hacia el enchufismo; el propio Francisco da abundosa noticia de todo esto con el completo panorama que ofrece del Lorca universitario en un libro definitivo para conocer tantos aspectos de su vida -y, por supuesto, el de su titulación como jurista-, Federico y su mundo ${ }^{172}$ : aunque cuatro años más pequeño, Paquito,

${ }^{168}$ Federico García LoRCA, Epistolario... cit., págs. 78-80 (c. de 27-¿VIII-1920?).

${ }^{169}$ Federico García LorCA, Epistolario... cit., págs. 83-84 (c. de antes del 9-X-1920).

${ }^{170}$ Federico García LORCA, Epistolario... cit., pág. 122 (c. de 2-VIII-1921).

${ }^{171}$ Federico GARCía LorCA, Epistolario... cit., págs. 161-162 (c. de comienzos de X-1922).

${ }^{172}$ Francisco García LorCA, Federico... cit., págs. 89-102. El pasaje -algo más de un capítulo- que Francisco consagra a la época universitaria de su celebérrimo hermano -en buena parte coincidente con la propia- constituye una atestación cualificada sobremanera y un bien entretejido relato de tanto a lo que el poeta apenas alude en las cartas aducidas, razón por la que no me resisto a copiar su trazo medular: partiendo de que, "aunque bien asistido por una excelente memoria, nunca, ni de muy chico, fue mi hermano un estudiante cumplidor", pues "era indisciplinado y mostraba escasísima inclinación al trabajo" (ibid., pág. 66), "después de aprobar el año preparatorio, que era común a Letras y Derecho, Federico había intentado primero la carrera de Letras" (ibid., pág. 90). "Las crecientes dificultades que encontró Federico en la Facultad de Letras, y la no muy grande presión de la familia, hicieron que fuese durante algunos años un estudiante nominal, y que probase fortuna luego en la Facultad de Derecho, en la que aprobó algunas asignaturas fáciles. Era aquel un momento de crisis en la Universidad [...]. Una serie de profesores caducos eran los titulares de las diversas materias, cuando éstas no eran regentadas por auxiliares poco atentos. Yo, cuatro años menor, asistía a la casi total renovación del personal universitario y a la elevación del tono académico, con profesores eminentes o eficazmente cumplidores en su mayoría. Con una Facultad de Derecho casi enteramente renovada tuvo que enfrentarse Federico cuando mi padre exigió de él que trabajase en la obtención de un título académico para seguir sufragando sus viajes a Madrid y sus largas estancias en la Residencia de Estudiantes, desde la cual Federico se puso en contacto con las nuevas generaciones literarias y artísticas. / Es lo cierto que mi hermano no interrumpió estos viajes y que mi padre costeó las ediciones de sus primeros li- 
según le llamaba el poeta, llegó a actuar para éste como su Virgilio en el infierno de los exámenes finales ${ }^{173}$. "Federico no quiso nunca abordar el tema de sus estudios" -nos dice aquél ${ }^{174}$-, y hasta tal extremo que ya "[...] no volvería jamás a mencionar su carrera universitaria ni a abrir un libro de derecho" ${ }^{175}$. Es así como se conduce en la Nota autobiográfica que pergeña hacia 1929 o 1930: ni rastro de la porfiada licenciatura ${ }^{176}$; y, para pleno convencimiento de su olvido del Derecho, nada como comprobar que, cuando al Poeta en Nueva York se le pase -fugazmente- por la cabeza la ocurrencia de sentarla,

bros sin dejar de ejercer presión sobre su hijo para que se graduase en 'algo'. La obtención de un título era para mi padre un prejuicio que compartían, creo, todos los padres de entonces. Quizá se añadía, en su caso, la actitud del labrador acomodado que quiere que sus hijos -y Federico era el mayor- tengan los títulos académicos que él no tuvo, ni tampoco sus propios hermanos, algunos naturalmente inclinados a las cosas del espíritu y más cultivados, de hecho, que cientos de licenciados. El título, en una sociedad entonces más cerrada que ahora, era vía de acceso a futuras posiciones. Nosotros teníamos que ser 'hombres de carrera'. [...] Pero mi padre, que no era ciertamente un iluso, no esperaba que su hijo pudiese ser algún día titular de una profesión liberal. Y si tuvo esta ilusión alguna vez, Federico se encargó de desengañarlo" (ibid., págs. 94-95). "Ya Federico había hecho sus primeras armas en el teatro y en la poesía y empezaba a ser conocido más allá de los límites comarcales cuando decidió acabar la carrera de Derecho" (ibid., pág. 95).

${ }^{173}$ Francisco García LorCa, Federico... cit., pág. 98: "Dios sabe con qué renuencia Federico se matriculó en la Universidad y con qué buena disposición se sometió a mi tutelaje en la tarea de preparar los exámenes. Era mi último año de carrera [1922-1923] y de algunas asignaturas nos examinamos al mismo tiempo". Y no menor fue la ayuda prestada por Agustín Viñuales, el catedrático de Economía Política (vide Salvador PéreZ Moreno et Manuel J. Delgado Martínez, "Viñuales Pardo, Agustín”, apud Peláez (ed.-coord.), Diccionario... cit., v. II, t. II, págs. 104-105), quien "[...] se dio cuenta de que Federico era un muchacho fuera de serie" (Francisco GARCía LoRCA, Federico... cit., pág. 97) y "[...] decidió hacer del poeta un licenciado en Derecho. Federico, en su primera etapa de estudiante, había logrado aprobar, no sé cómo, algunas asignaturas, no de las menos arduas; los Civiles, por ejemplo. De todos modos, tenía media carrera pendiente. Don Agustín planteó el 'caso Federico' a la Facultad. Al notorio y joven poeta le exigía su familia la obtención de un título para facilitarle la profesión de su verdadera 'carrera': la literaria. La cultura del poeta era superior, con mucho, a la media estudiantil. La tradición humanística de nuestras Facultades de Derecho se inclinaba más a la formación cultural que profesional del estudiante. Federico era un caso excepcional y sería poco justo aplicarle criterios puramente académicos. La Universidad granadina encontraría con el tiempo, no ya la justificación de un trato de excepción, sino un motivo de orgullo'. Estos, creo yo, fueron los argumentos de don Agustín" (ibid., pág. 98).

${ }^{174}$ Francisco GARCía LoRCA, Federico ... cit., pág. 102.

${ }^{175}$ GiBson, Vida ... cit., pág. 156.

${ }^{176}$ Federico García LorCA, "Nota autobiográfica", en Obras completas, recop. Arturo del Hoyo, Aguilar, Madrid, 1960, págs. 1656-1657.

${ }^{177}$ Federico GARCÍA LORCA, Epistolario... cit., págs. 366-367 (c. 2-IX-1926), en consulta a Guillén: "yo he decidido prepararme para unas oposiciones a cátedra de Literatura, pues creo que tengo vocación (lentamente va surgiendo en mí) y capacidad de entusiasmo [...]. / Yo estoy decidido y quiero decidirme más, pero no sé cómo se hacen las cosas. Desde luego tendré que darme grandes golpes en la cabeza para realizar esto, pero yo no como, ni bebo, ni entiendo más que en la Poesía. [...] Yo no tengo prisa, pero quiero hacer esto para justificar mi actitud (ya de- 
de estabilizar su vida - estar colocado, dice él-y decida opositar, sólo pensará en unas oposiciones a cátedra de Literatura ${ }^{177} \ldots$

\section{III.5. Manuel Altolaguirre}

Es Manuel Altolaguirre (1905-1959) un miembro menor de la Generación del 27 o, en justicia, simplemente no tan famoso como sus compañeros en ella ${ }^{178}$, aunque seguirá todavía siendo menor si atendemos a su condición de benjamín del grupo: había nacido en 1905. Tuvo, además de la poesía, pero muy entroncada con ella, otra pasión: la de tipógrafo y editor ${ }^{179}$. En plano inferior de sus reflexiones y recuerdos, aparece él mismo "[...] durante el tiempo que hacía mis estudios universitarios de derecho" ${ }^{180}$, con García Lorca como condiscípulo recordado bajo el magisterio del iuspolitólogo Fernando de los Ríos $^{181}$. La nota biográfica que introduce su aporte a la Antología de Gerardo Diego es de propia mano y en ella declaraba sus estudios, pero puntualizando ipso facto que otro era su medio de ganarse - malamente- la vida:

Soy licenciado en Derecho. Como obrero, soy tipógrafo y el único impresor de mis libros y revistas, que hago en un pequeño taller que he instalado en mi cuarto y que me acompaña en mis viajes ${ }^{182}$.

finitiva) poética. / Por otra parte no tengo otra salida y siento mi voz pobre iluminada en las salas bajas de las otras gentes... y además... ¿está eso mal pensado?.. ¿Es que yo no puedo hacerlo?”; "porque yo necesito estar colocado. Figúrate que quisiera casarme. ¿Podría hacerlo? No. Y esto es lo que quiero solucionar" (ibid., pág. 369 [c. 9-IX-1926]).

${ }^{178}$ Vicente Tusón et Fernando LÁZARO, Literatura española, Anaya, Madrid, 1984, pág. 334: “рpoeta menor? Sólo la inmensa talla de otros miembros del grupo puede explicar que se le haya tenido como tal. Él mismo [...] se colocaba a la sombra de poetas mayores". De hecho, como constata James VALENDER (ed.), "Introducción" a Manuel Altolaguirre, Epistolario (1925-1959), Residencia de Estudiantes, Madrid, 2005, pág. XLVII, "Manuel Altolaguirre es uno de los poetas menos estudiados de su generación".

${ }^{179}$ Vide José Luis Bernal SALGADO, "Manuel Altolaguirre, impresor y editor de poesía", en Joaquín Roses (coord.-ed.), Manuel Altolaguirre, el poeta impresor, Diputación de Córdoba, Córdoba, 2005, págs. 81-100; o NeIRA, Manuel... cit., in totum.

${ }^{180}$ Manuel AltolaguirRe, "El caballo griego", en Obras completas, ed. James Valender, Istmo, Madrid, 1986, t. I, pág. 38.

${ }^{181}$ Altolaguirre, "Recuerdos de Federico García Lorca”, en Obras... cit., págs. 280282. Vide Manuel J. Peláez, "Ríos Urruti, Fernando de los", apud id. (ed.-coord.), Diccionario... cit., v. II, t. I, págs. 392-396.

182 Manuel Altolaguirre, "Vida", en vv. Aa., Poesía ... cit., pág. 447. A mayor abundamiento, ID., Epistolario... cit., pág. 39 (c. 14, 2-VIII-1926), ante la Caja de Recluta de Málaga declara: "oficio Estudiante"; y un año después, ibid., pág. 85 (c. 20-VII-1927), "abogado". Peticionario en 1933 a la Junta de Ampliación de Estudios, que de resultas lo pensionó año y medio en Londres para seguir investigaciones filológicas, se presenta como "Licenciado en Derecho" (ibid., pág. 258 [c. 255, 8-II-1933]). Con Falla se lamenta, al pretender un puesto de lector en Cambridge, de "[...] que no soy licenciado en Letras; soy abogado únicamente" (ibid., pág. 277 [c. 274, 26-III-1934]). 
Dice menos de lo que da a entender acerca de la propia elección de carrera -por una vez, a lo que parece, no enjaretada directamente por la familia-; acompañemos al poeta impresor en su decurso:

Aprobado que fui en mi examen de Preceptiva literaria, finalicé con éxito mi bachillerato y emprendí de modo tan vertiginoso la carrera de leyes que a los dos años me gradué como abogado en la Universidad de Granada, para lo cual tuve que ganar asignaturas durante los veranos, cosa que hice para estar pronto en condiciones de ayudar económicamente a mi madre, viuda con siete hijos, que mucho lo necesitaba. Siendo pues casi un niño, le escribí a don Francisco Bergamín la siguiente carta:

«Mi querido amigo y compañero: Habiendo finalizado mis estudios jurídicos y necesitando añadir a mis conocimientos teóricos la experiencia necesaria para el ejercicio de mi profesión, me permito recordarle su buena amistad con mi difunto padre (q. e. p. d.) para rogarle me acepte como pasante en su bufete, señalado servicio que le agradecerá siempre su affmo. amigo q. e. s. m.» ${ }^{183}$

Él mismo revela y comenta el resultado de la gestión substanciada ante este Bergamín, catedrático, diputado, senador, ministro, abogado y padre del poeta fundador de Cruz y Raya:

Esta carta tuvo un éxito inesperado. A vuelta de correo recibí del señor Ministro contestación de su puño y letra concediéndome la plaza solicitada en su bufete. Y si la sorpresa fue grande para mí, aún produjo mayor impresión en mi madre que, llena de ilusiones, se apresuró a proporcionarme todo lo necesario para mi traslado a la Corte, viaje que realicé a los pocos días. [...] Todos se asombraban de que tan joven hubiera obtenido distinción tan extraordinaria, ya que para merecerla yo necesitaría por lo menos algunos años más. Sin embargo, a pesar de mis verdes conocimientos, don Francisco Bergamín me recibió con gran cordialidad e hizo todo lo posible para que yo adelantase en mi carrera. Aquel hombre tan inteligente sin duda adivinó mi incapacidad, pero tuvo buen cuidado de no desalentarme. Con su hijo Pepe me hacía trabajar en materias de derecho, a las que ninguno de los dos atendíamos. Otras eran ya nuestras aficiones. Andando el tiempo nuestro campo sería el de la literatura y en lugar de atender entonces a los litigios comentábamos lecturas recientes, conversaciones a las que debo mucho de mi formación literaria.

[...] Por lo anteriormente dicho se adivinará mi fracaso en la abogacía. En efecto, a los pocos meses tuve que regresarme a Málaga ${ }^{184}$.

${ }^{183}$ AltolaguirRe, "El caballo..." cit., pág. 42 (la fecha de la esquela se aproxima en ID., Epistolario... cit., pág. 27 [c. 1, primavera de 1925]). Y vide Manuel J. PelÁEz, "Bergamín García, Francisco", apud id. (ed.-coord.), Diccionario... cit., v. I, pág. 147.

${ }^{184}$ Altolaguirre, "El caballo..." cit., págs. 42-43. VAlender, "Notas" a Altolaguirre, Epistolario... cit., pág. 28, amplía que "[...] se sabe que el 5 de mayo de 1925 Altolaguirre trasladó su expediente estudiantil a la Universidad de Madrid". 
Con todo, el malagueño parece aceptar su fracaso sólo en eso, en la abogacía, pero no globalmente en el Derecho y ensaya, sin sustraerse a idéntico desenlace, otras vías para salir adelante con su ejercicio: primero, opta por doctorarse ${ }^{185}$; y más tarde da en las dos mismas ocurrencias que su íntimo amigo Cernuda, es decir, le tienta el puesto de secretario de ayuntamiento ${ }^{186}$ y acusa idénticas veleidades diplomáticas: entre licenciado y obrero, insertaba Altolaguirre en el apunte epistolar que remitió a Diego un inciso que éste, seguramente al tanto de su sola función de pretexto para el viaje, suprimió al pasarlo a la Antología:

Soy Licenciado en Derecho y preparo en la Escuela de Altos Estudios Políticos de París mi ingreso en la carrera diplomática española ${ }^{187}$.

El cantor de Las islas invitadas confiesa a Guillén lo que de auténtico hay en tales designios de última hora:

El pretexto de mi viaje es preparar las oposiciones al cuerpo diplomático, pero es posible que me engañe yo mismo y no haga nada práctico esta vez tampoco. Escribir si ${ }^{188}$.

${ }^{185}$ Altolaguirre, Epistolario... cit., pág. 33 (c. 5, 15-VII-1925), escribe a Sánchez Cuesta: "mucho le agradeceré que al recibo de ésta me remita con la mayor urgencia los libros textos y programas del doctorado de Derecho y que a ser posible, caso de no serle de una molestia excesiva, me indique hasta qué lecciones exigen de las asignaturas cuyos textos solicito. [...] Las asignaturas son: / Antropología criminal. / Historia de la literatura jurídica española. / Política social. / Historia del derecho internacional". De este propósito nunca más se supo...

${ }^{186}$ Altolaguirre, Epistolario... cit., pág. 141 (c. 126, 7-X-1928), hace partícipe a Juan Guerrero "[...] de que me estoy preparando para las oposiciones de Secretarios de Ayuntamiento. (Pronto seremos compañeros.)", para lo cual el de Murcia debió de brindarle algún valimiento, pues en su siguiente carta el opositor, ibid., pág. 143 (c. 128, 28-XI-1928), le cumplimenta: "mucho te agradezco lo que me ofreces hacer por mí cuando sean las oposiciones. Ya te avisaré con tiempo". Altolaguirre venía informando a varios amigos desde abril de este año 28 de su nuevo quehacer: a Villalón (ibid., pág. 121 [c. 109, IV-1928]), a Diego (ibid., pág. 124 [c. 111,27-IV-1928]), a José María de Cossío (ibid., pág. 128 [c. 116, V/VI1928]); las alusiones continúan hasta la primavera del 29 (ibid., pág. 152 [c. 137, 9-II-1929]; pág. 153 [c. 138, 3-IV-1929]; pág. 155 [c. 139, IV-1929]). Vicente AlEIXANDRE, Epistolario de Vicente Aleixandre a Juan Guerrero y a Jorge Guillén, ed. Gabriele Morelli, Universidad de Alcalá/Caballo Griego para la Poesía, Madrid, 1998, págs. 60-61 (c. de 1-IV-1929), se lo cuenta a un Guerrero Ruiz bien sabedor: "Altolaguirre estudia y vendrá a Madrid a examinarse: quiere ser secretario de ayuntamiento (pero no de Murcia, claro)". Vide Altolaguirre, Epistolario... cit., pág. 152 (c. 137, 9-II-1929).

${ }^{187}$ Altolaguirre, Epistolario... cit., pág. 188 (c. 179, 18-XII-1930, fechada, sí, en París).

${ }^{188}$ Altolaguirre, Epistolario... cit., pág. 181 (c. 171, IX-1930). El repaso al correo parisiense, desde el otoño del año 30 (ibid., pág. 185 [c. 176, de 24-XI-1930]) hasta el verano del 31 (ibid., pág. 226 [c. 217, de finales de VII-1931]), confirma todas las sospechas, con un Altolaguirre inmerso en el ajetreo tipográfico e indiferente por completo a los altos estudios políticos... Ya vecino londinense en 1933, "quisiera que me nombraran agregado cultural en la Embajada en Londres” (ibid., pág. 265 [c. 263, 8-VIII-1933]). 
Él solo se lo estaba diciendo todo... Ahora, la motivación no puede ser más peregrina -más contra ingenio- y da la medida de la vocación jurídica que lo animaba: caballero en El caballo griego, arrostra la reminiscencia de "la novia de mi primera juventud, a quien quise mucho", Gracia Canivell Frietes de Molina, y...

Nunca conocí a nadie con un aspecto de felicidad exterior como la suya. En su familia la fortuna había entrado a raudales. [...] Gracita tuvo una juventud llena de regalos. Gozaba infantilmente estrenando en cada reunión un traje $[\ldots]$.

Para complacerle, dejé Málaga para ir a estudiar Ciencias Políticas en la Universidad de París. El motivo de mi viaje era mejorar mi preparación para presentarme en las oposiciones al Cuerpo Diplomático. Me inclinaba hacia esos estudios el pensar que Gracia sería feliz en el ambiente social de mi carrera $^{189}$.

Altolaguirre, aunque él sin vislumbres de desgarro, es el caso más propincuo a Cernuda: en verdad que "es lástima ver a un hombre trabajar y quebrarse la cabeza en cosa que es imposible salir con ella" ${ }^{190} \ldots$

\section{Recapitulación}

Conque tenemos a Pedro Salinas desistiendo de su acometida carrera de jurista. No así Dámaso Alonso, quien, licenciándose por duplicado, supo o pudo enmendar el erróneo escogimiento jurídico inicial. Recorrió García Lorca el camino inverso a los dos primeros: de Letras dio en Derecho, abandonando aquellas enseñanzas, pero con resultancias parcamente proficuas. Aleixandre vivió -malvivió en sus adentros- de sus titulaciones oficiales hasta la postración física que bien temprano (1925) lo incapacitó laboralmente. Cernuda y Altolaguirre no cursaron más que Leyes en la Universidad y nunca se lucrarían con su ejercicio. El sevillano quiso y no pudo..., o pareció querer, o creyó querer... En definitiva, tan providencial como fue la enfermedad para el Aleixandre poeta -por supuesto, sólo en este sentido creativo ${ }^{191}$-, debió de ser el fracaso opositor para Cernuda, en adelante ya siempre nómada y a la intemperie económico-social. El poeta de La voz a ti debida le llamó una vez Licenciado Vidriera ${ }^{192}$, para su disgusto. La verdad es que, desde nuestra perspectiva, también de él cuadra predicar lo que Cervantes de su inmarcesible

${ }^{189}$ Altolaguirre, "El caballo...” cit., págs. 89-90.

${ }^{190}$ HuARTE de SAN JuAn, Examen... cit., pág. 152.

${ }^{191}$ El poeta tiene bien diagnosticada "[...] la larga dolencia que torció -o enderezó- el curso de una vida" (ALEIXANDRE, "Los encuentros" cit., pág. 1611), y cuyo sentido teleológico ha percibido con tanta perspicuidad LuIs, Vida ... cit., pág. 95: "el dolor físico ha impreso decisivo rumbo en el vivir de este poeta, que acaso sin esa heridora y reiterada experiencia no hubiera cumplido su destino plenamente" (y vide la nota 161).

${ }^{192} \mathrm{Cfr}$. nota 20. 
personaje Tomás Rueda, otro letrado por partida doble -y, circularmente, topamos con nueva anfibología-: que "su principal estudio fué de leyes, pero en lo que más se mostraba era en letras humanas"193.

${ }^{193}$ Miguel de Cervantes, "El licenciado Vidriera", en Novelas ejemplares, ed. Francisco Alonso, EDAF, Madrid, 1986, pág. 252. Conforme advierte Ivo DomínguEZ, El Derecho como recurso literario en las Novelas ejemplares de Cervantes, ed. Julio Ricci, Instituto de Estudios Superiores de Montevideo, Montevideo, 1972, pág. 50, "si intentáramos comentar todos los elementos jurídicos que aparecen en 'El licenciado Vidriera', lo tendríamos que hacer en casi todas sus páginas, pues por razón de la profesión del protagonista, las alusiones y referencias al Derecho resultan sumamente abundantes", “[...] pues Cervantes en esta ocasión seleccionó como figura central de toda la trama a un joven graduado de licenciado en Leyes" (ibid., pág. 49). 